\title{
YTTRIA-STABILIZED ZIRCONIA SOLID OXIDE ELECTROLYTE FUEL CELLS MONOLITHIC SOLID OXIDE FUEL CELLS
}

\author{
DOE/MC/25166--T13 QUARTERLY REPORT \\ DE92 017798 \\ APRIL - JUNE 1989 \\ 88-61845(4) \\ Contract DE-AC21-88MC2.5166
}

Prepared for

U.S. Departrnent of Energy Morgantown Energy Technology Center Morgantown, WV
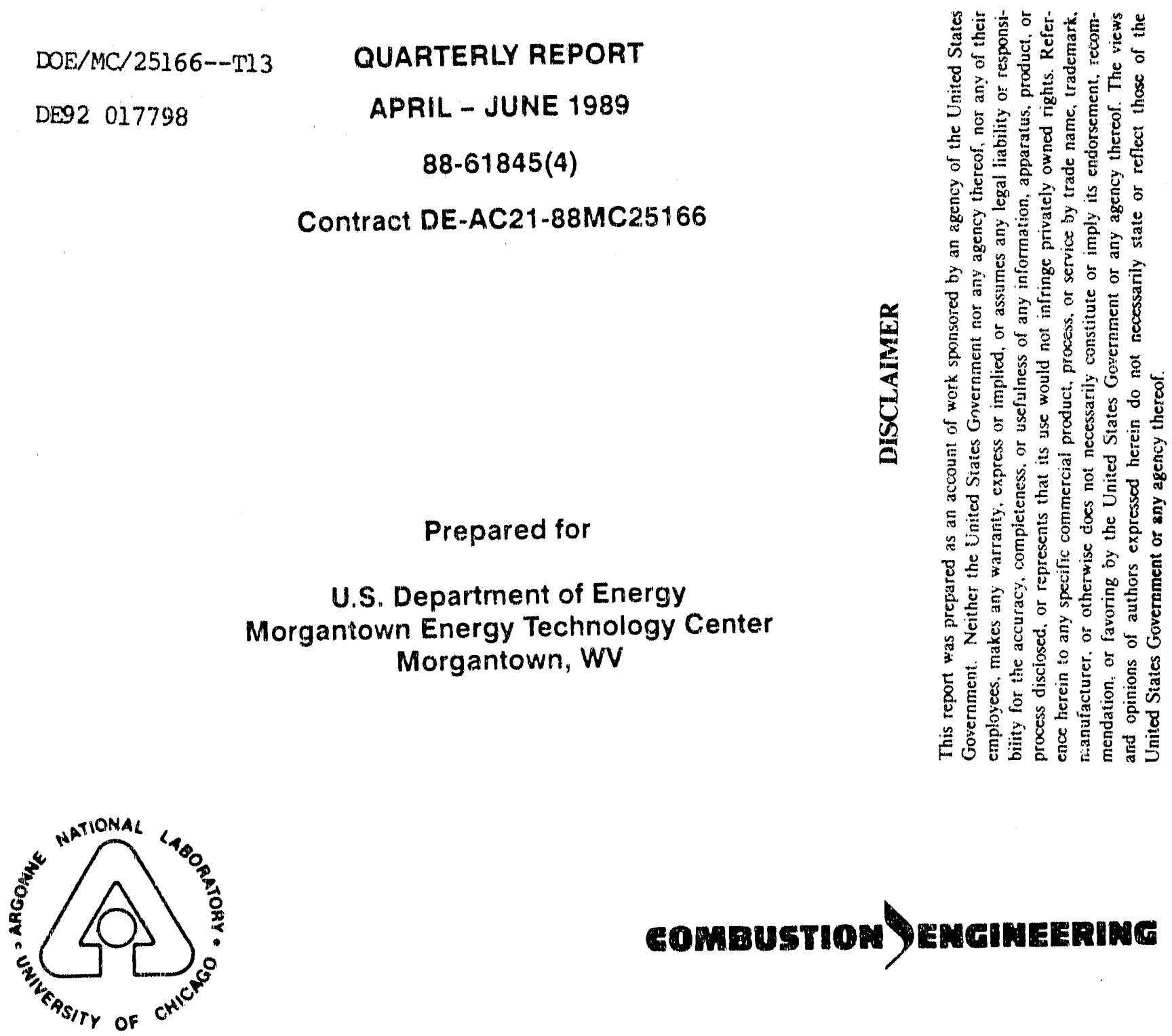

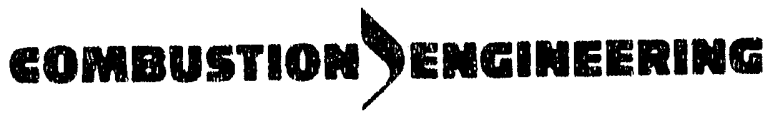

AHRsearch Los Angeles Division HA

Allied-Signal Aerospace Company 


\section{INTRODUCTION}

This report describes the work performed on the U.S. Department of Energy (DOE)/Morgantown Energy Technology Center (METC) program, titled "Yttria-Stabilized Zirconia Solid Oxide Electrolyte Fuel Cells, Monolithic Solid Oxide Fuel Cells", during the period April through June 1989 (Contract DE-AC21-88MC25166). The program is conducted by the team consisting of Allied-Signal Aerospace Company, AiResearch Los Angeles Division (AiResearch), Argonne National Laboratory (ANL), and Combustion Engineering (CE). This program is part of the DOE program to identify advancements for fuel cells that offer significant improvements in performance, cost, and life over current goals. This program is focused on the monolithic design of solid oxide fuel cells. The specific objectives of this program are to:

i Assess the manufacturing costs for a monolithlic solid oxide fuel cell (MSOFC) and system costs for a coal-based MSOFC plant.

ii Modify electrode/electrolyte interfaces to improve the electrochemical performance of the MSOFC.

iii Test the performance of a MSOFC on simulated coal-derived fuels under specified test conditions. 


\section{BACKGROUND ON MONOLITHIC SOLID OXIDE FUEL CELLS}

The monolithic solid oxide fuel cell (MSOFC) is a recent design concept in fuel cell technology. The design employs thin ceramic layer components to form a compact, lightweight solid state structure. The MSOFC is composed of small cells bonded into a single structure much like a block of corrugated paperboard.

The key to this design is that the cells are very small ( 1 to $2 \mathrm{~mm}$ is the repeat distance from cell to cell) and the ceramic active cornponents are also the structural components of the cells. The monolithic design eliminates inactive structural support, increases active surface areas, and lowers voltage losses due to internal electrical resistance. The fuel cell thus has high efficiency, excellent performance, and high power density. Along with high efficiency and high power density, the MSOFC can also offer fuel flexibility, potential low-cost manufacturing, low operational and maintenan e requirements, and envircnmental acceptability. The monolithic fuel cell can be integrcied with coal gasification plants and is expected to have high overall efficiency in the conversion of the chemical energy of coal to electrical energy.

In an MSOFC, fuel and oxidant produce a dc current by combining electrochemically across the solid oxide electrolyte at an operating temperature of $1000^{\circ} \mathrm{C}$. In the coflow version, the monolithic fuel cell consists of a honeycomb-like array of adjacent fuel and oxidant channels that resemble corrugated paperboard (Figure 2-1). Oxidant channels are lined with a porous cathode ( $\mathrm{Sr}$-doped $\mathrm{La} \mathrm{MnO}_{3}$ ), and fuel channels are lined with a porous anode $\mathrm{Ni} / \mathrm{Y}_{2} \mathrm{O}_{3}$-stabilized $\left.\mathrm{ZrO}_{2}\right)$. A gas-tight layer of electrolyte $\left(\mathrm{Y}_{2} \mathrm{O}_{3}\right.$-stabilized $\left.\mathrm{ZrO} 2\right)$ is located between the anode and cathode. An interconnect (doped $\mathrm{LaCrO}_{3}$ ), which is also gas-tight, connects the cells in electrical series. Typical thickness of the layers is 25 to 100 microns, and the distance from cell to cell is 1 to $2 \mathrm{~mm}$. As can be seen from Figure 2-1, the coflow MSOFC is made of two types of laminated structures, each composed of three ceramics-anode/electrolyte/cathode and anode/interconnect/cathode. The laminated structure containing the electrolyte is appropriately corrugated. The corrugations form the gas seals at the edges of the monolithic structure. Gas manifolding for the coflow MSOFC is complex, involving a transition section in which the oxidant flow is diverted to one side and the fuel flow to the other side of gas manifolds. In the crossflow version, the fuel and oxidant flow through channels formed by corrugated anode and cathode layers (Figure 2-2). The fuel and oxidant channels are at right angle to each other. The anode/electrolyte/cathode and anode/interconnect/cathode laminated structures are flat and stacked alternately between the corrugated anode and cathode layers. The crossflow version offers a simpler meanc of ducting gases in and out of the monolithic fuel cell. The crossflow design, however, results in a reduction in power density by a factor of about two below that of the coflow design.

Small cell size, thin ceramic components, and high operating temperature are the key features of the MSOFC. The small size of individual cells in the monolithic structure increases the active surface area. For example, an MSOFC with channels about $1 \mathrm{~mm}$ in diameter has a ratio of active surface area to volume of about $9.4 \mathrm{sq} \mathrm{cm} / \mathrm{cu} \mathrm{cm}$. This is about seven times the ratio for conventional fuel cells. On this basis alone, an MSOFC with a 


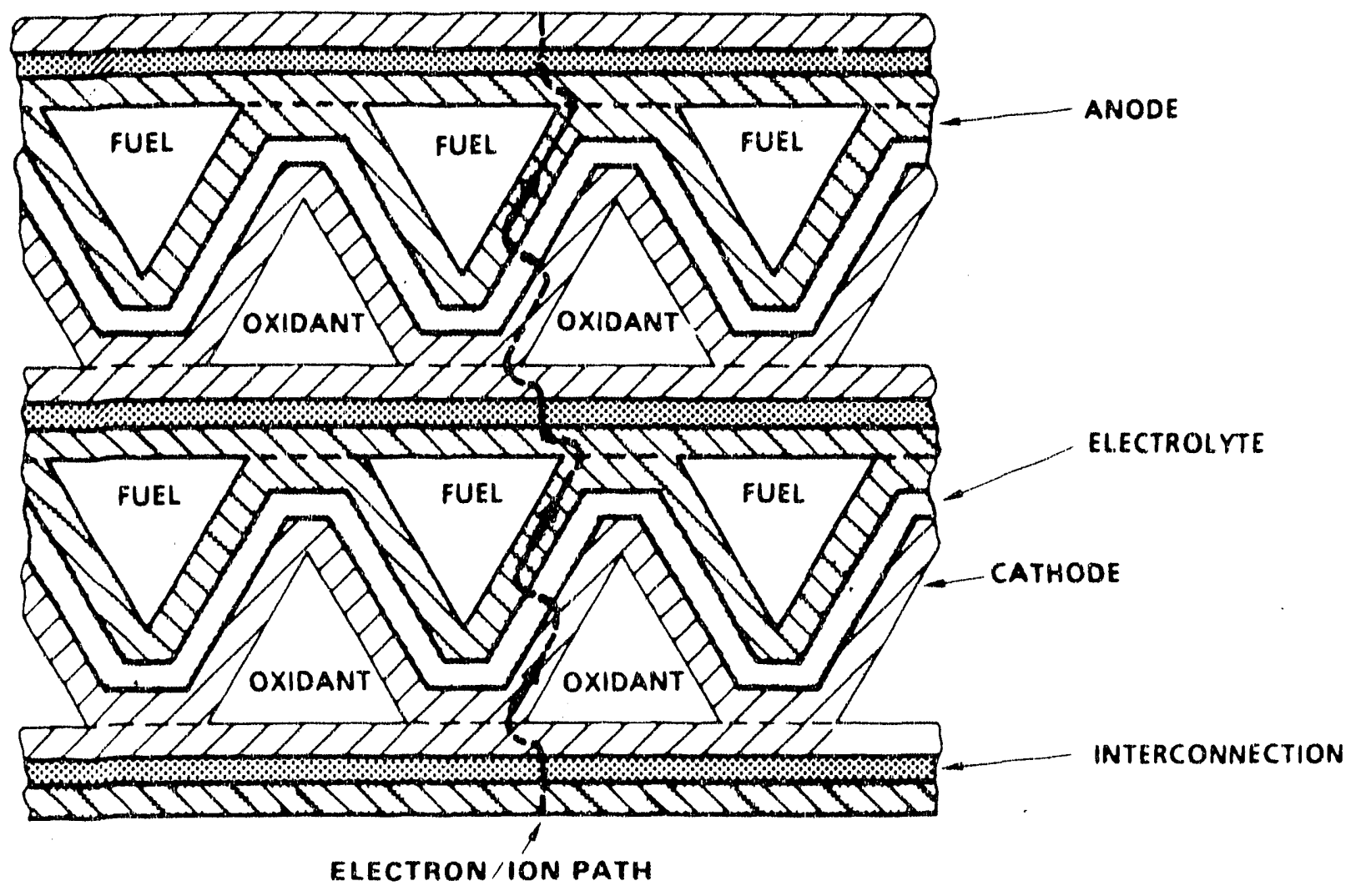

Figure 2-1. Coflow Monolithic Solid Oxide Fuel Cell 


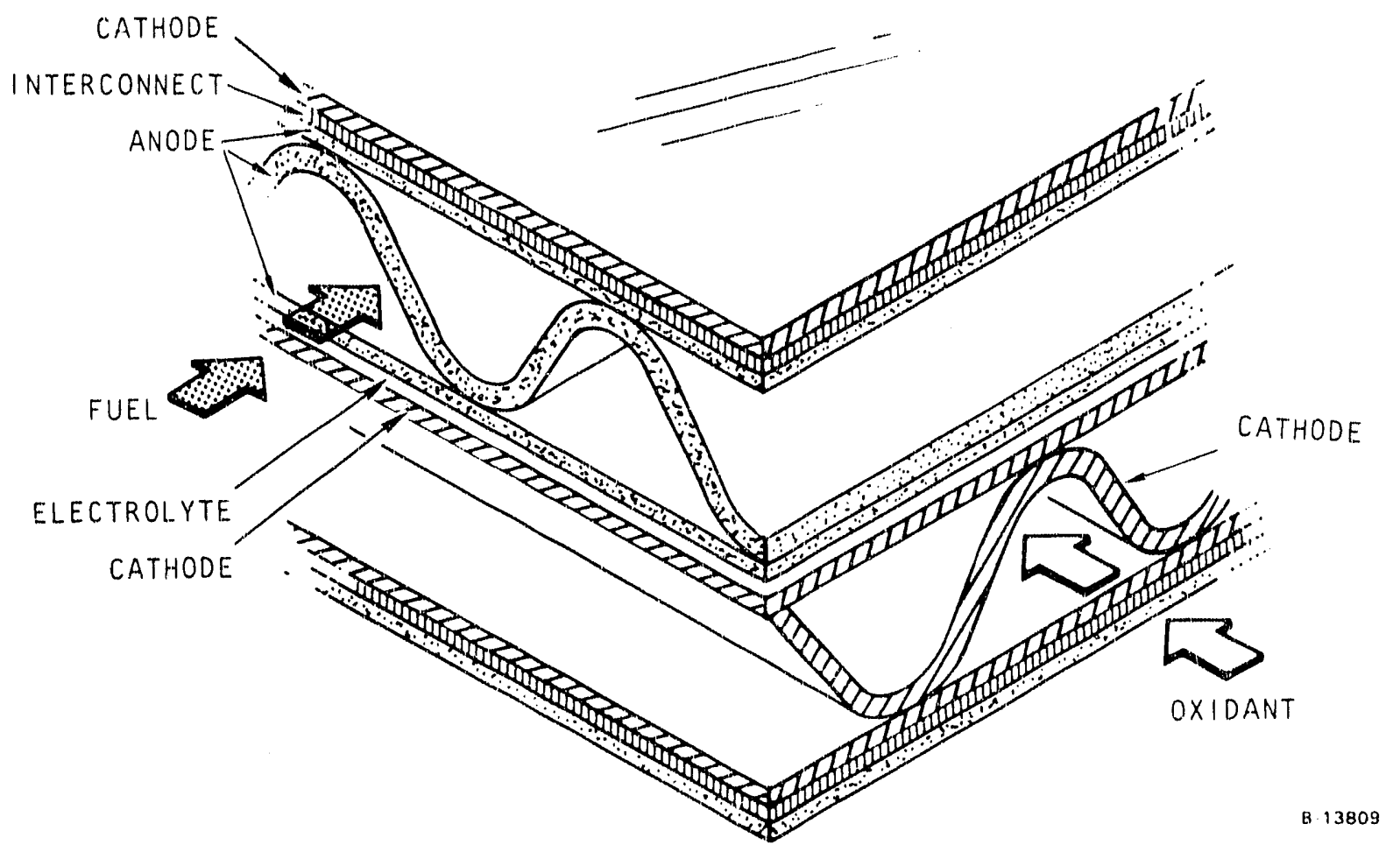

Figure 2-2. Crossflow Monolithic Solid Oxide Fuel Cell 
channel diameter of $1 \mathrm{~mm}$ should produce the same power as a conventional fuel cell seven times as large.

More importantly, the small cell size in the MSOFC reduces voltage losses due to internal electrical resistance. Because current is carried in-plane by the electrodes in both conventional and monolithic designs, a decrease in the cell size decreases the internal electrical resistance. In MSOFCs, the major source of internal voltage loss is the resistance that electrons encounter in the cell's ceramic components. Inside the operating fuel cell, an oxidation reaction (the electrochemical reaction of hydrogen fuel) releases electrons on the anode side of the barrier that separates oxygen channels from fuel channels. Flowing along the anode, electrons travel around the fuel channel wall and across the interconnection to the cathode of the adjoining oxygen channel (Figure 2-1). The electrons then flow along the cathode, around the oxygen channel to the cathode/electrolyte interface, where they are consumed in a reaction (with oxygen) that produces an oxide ion. The oxide ion is transported through the plane of the electrolyte, reacts with hydrogen on the fuel side of the electrolyte to produce electrons, and the process continues. In this way, the electron current traverses the multicell monolithic structure. Because individual cells in the monolithic fuel cell are small, electron/ion paths are short and resistive losses are low. As a result of lower internal resistance, the MSOFC can be operated at higher current densities than conventional fuel cells while achieving the same output voltage.

The high current density of the MSOFC results from the small cell size and ensuing low internal resistance. The current density is high at the fuel inlet end of the fuel channel where the thermodynamic driving force (Nernst potertial) is highest, as shown in Figure 2-3. Similarly, the current density is low at the outlet end of the fuel channel where the Nernst potential is lowest. The low current density at the fuel outlet is desirable because overall cell performance is determined by the voltage losses due to internal resistance at the cell outlet. (Voltage losses arising from resistance to gas phase diffusion are negligible due to the thin electrodes.) Small resistance polarization losses (1 to $5 \mathrm{mV}$ ) at the fuel outlet mean that the fuel electrode, as an equipotential surface, approaches the maximum theoreticial voltage set by thermodynamic conditions. The optimum cell performance is obtained when the average current density is increased to the point where resistance polarization losses at the fuel outlet just become significant, as shown in Figure 2-3. As a result, the cell nearly always operates within a percent or so of the maximum efficiency, even at high power output.

Because of the high operating temperature of the MSOFC $\left(1000^{\circ} \mathrm{C}\right)$, hydrocarbon fuels can be reformed in the fuel channels. The reform reaction produces hydrogen which is consumed by the fuel cell, and this reform reaction is illustrated by

$$
\mathrm{CH}_{4}+\mathrm{H}_{2} \mathrm{O}-\cdots>\mathrm{CO}+3 \mathrm{H}_{2}
$$

Catalytic reforming of methane and natural gas within a solid oxide fuel cell has been demonstrated. Reforming of higher weight hydrocarbons should proceed rapidly at the conditions of the MSOFC. 


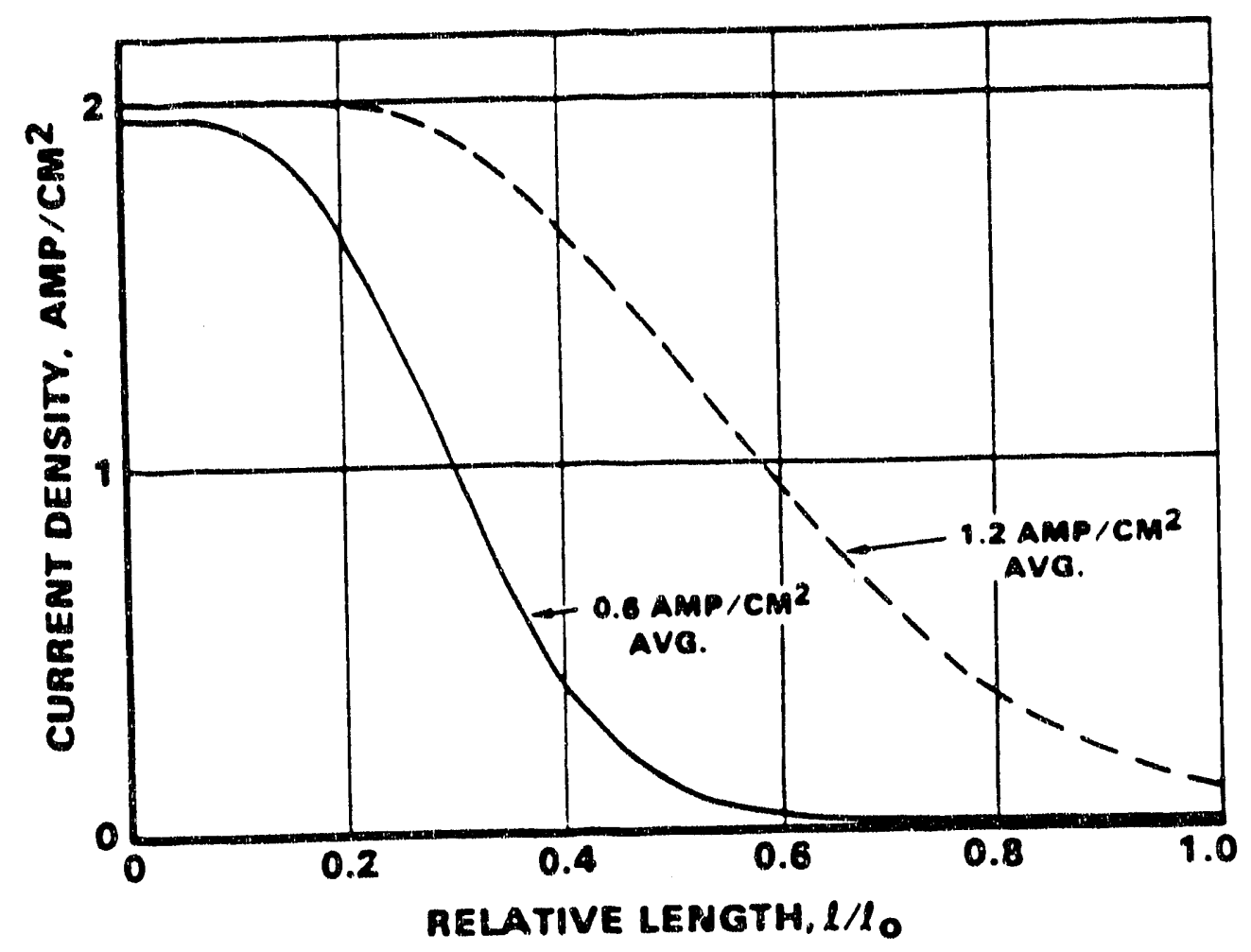

Figure 2-3. Axial Current Distribution Along Fuel Channel (Fuel Eriters at Relative Length of 0 and Exits at Relative Length of 1.0)

The MSOFC features of thin ceramic components, small cell size, and $1000^{\circ} \mathrm{C}$ operating temperature combine to provide very high power densities of about $8 \mathrm{~kW} / \mathrm{kg}$ or 4 $\mathrm{kW} / \mathrm{L}$ for the MSOFC (fuel cell only, coflow version). This very high power density cuupled with expected efficiencies of over 50 percerit offers the possibility of successful competition with existing electrical generation systems. The ability of the MSOFC to reform hydrocarbon fuels within the fuel channels allows existing fuels and fuel distribution methods to be used with minor modifications for most applications. The power density of the MSOFC is high enou'gh to meet the demands of many diverse applications such as aerospace, transportation, portable power systems, and micro-cogeneration systems, as well as more conventional utilities systems. The challenge is to fabricate the MSOFC structure by co-sintering all four fuel cell materials into the corrugated "honeycomb" structure (stack). 


\section{COST STUDY}

\subsection{OBJECTIVE}

The objectives of the cost study are:

(i) To assess the manufacturing cost for the MSOFC assuming a nominal production rate of $200 \mathrm{MW} /$ year for coal-based system applications.

(ii) To define an integrated coal gasification MSOFC system with a potential for reducing plant heat rate and capital costs below 7,100 BTU/kWh and $\$ 1,300 / \mathrm{kW}$, respectively.

\subsection{MANUFACTURING COST STUDY}

The eight flow charts detailing the major stages of the MSOFC manufacturing process were finalized during this reporting period and released for use in the next stage of the cost study. The eight flow charts are:

(1) Master flow chart outlining the overall fabrication process of a MSOFC $50 \mathrm{~kW}$ stack.

(2) Anode fabrication flow chart.

(3) Electrolyte fabrication flow chart.

(4) Cathode fabrisation flow chart.

(5) Interconnect fabrication flow chart.

(6) Reprocessing plant design.

(7) Plant layout.

(8) End plate and gas conduit fabrication flow chart.

The flow charts are being reviewed to establish equipment requirements and costs necessary to accomplish the quantities and through-put rates that have been established. A list of vendors who would be the suppliers of the manufacturing equipment has been compiled, and contact has been initiated. In addition to performing the review of the flow charts, cost factor guidelines for the cost study are being established. 
4. IMPROVE MSOFC ELECTROCHEMICAL PERFORMANCE (INTERFACIAL MODIFICATION)

\subsection{OBJECTIVE}

The objective of the interfacial study is to modify electrodes and electrode/electrolyte interfaces of the MSOFC to improve its electrochemical performance. Specifically, characteristics of the electrode/electrolyte interfaces will be tailored to reduce interfacial resistance.

\subsection{INTERFACIAL MODIFICATIONS}

In the last reporting period (January-March 1989), several single cells and electrode/ electrolyte composites were fabricated to exarnine the effect of cathode bonding and cathode/e'ectrolyte intermediate layer on interfacial resistance. The construction of the fabricated samples is summarized in Table 4-1.

\begin{tabular}{|c|c|c|}
\hline \multicolumn{3}{|c|}{ TABLE 4-1 } \\
\hline Sample Type & \multicolumn{1}{|c|}{ Construction } & Thickness Ratio \\
\hline Single cell & A:E:CE:C & $1: 5: 1: 1$ \\
& A:E:CE & $1: 5: 1$ \\
& A:E:C (with solvent bonding & $1: 5: 1$ \\
& A:E:C & $1: 5: 1$ \\
& \multicolumn{1}{|c|}{ between layers) } \\
Electrode/ & A:E:A & $1: 5: 1$ \\
electrolyte & CE:E:CE & $1: 5: 1$ \\
composite & C:E:C & $1: 5: 1$ \\
& C:E:C (with solvent bonding & $1: 5: 1$ \\
& \multicolumn{1}{|c|}{ between layers) } \\
\hline
\end{tabular}

The samples were fired at $1350^{\circ} \mathrm{C}$ for $0.5 \mathrm{hr}$ in air. The samples fired under these conditions were flat, and none were cracked or delaminated. Some of the fired samples were examined by optical and scanning electron microscopy. Figures 4-1 to 4-3 show the optical micrographs of polished cross-sections of $C E: E: C E$ and $C: E: C$ cathode/electrolyte composites.

In these micrographs, porosity can be seen as black spots. It can be seen from the figures that the electrolyte is dense while the cathode and cathode/electrolyte layers are porous. The cathode (C) layer is much more porous than the cathode/electrolyte intermediate (CE) layer. The bonding between cathode and electrolyte layers appears to be quite good. Comparison of Figures 4-2 and 4-3 indicates no significant differences between 

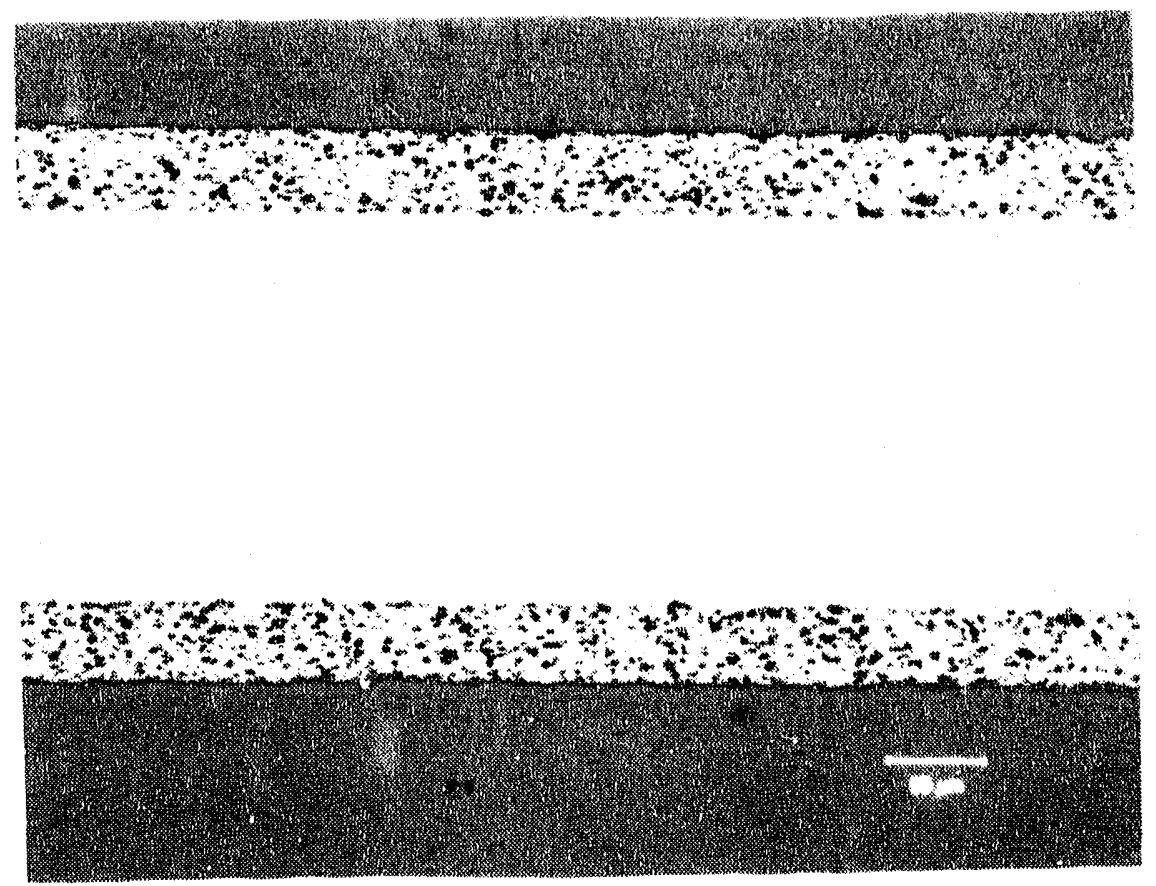

Figure 4-1. Optical Micrograph of CE:E:CE Composite (METC 15-07)
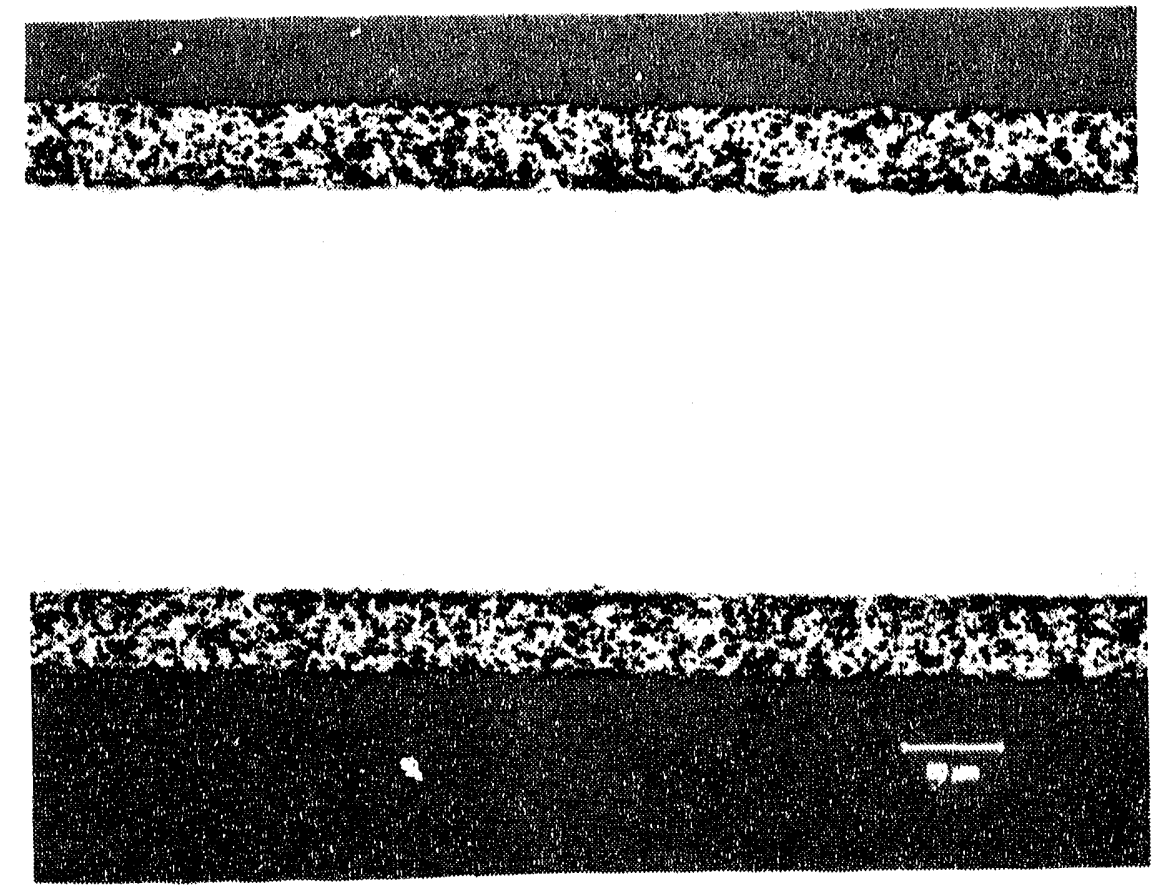

Figure 4-2. Optical Micrograph of C:E:C Composite (METC 15-06) (No Solvent Bonding) 

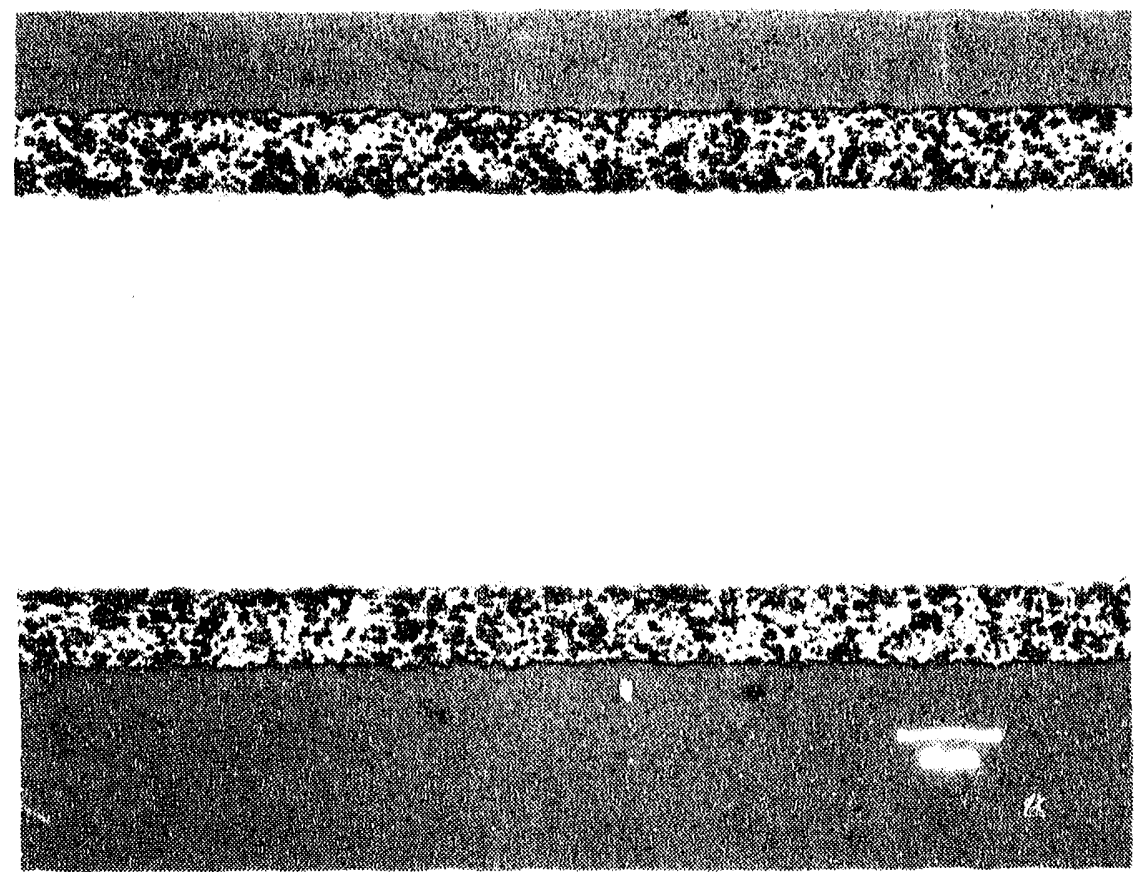

Figure 4-3. Optical Micrograph of C:E:C Composite (with Solvent Bonding) (METC15-08)

cathode/electrolyte interfaces in composite samples with and without solvent bonding. Figures 4-4 and 4-5 show typical micrographs of $A: E$ :CE and $A: E: C$ single cells. The large crack in the middle of the electrolyte in these photographs is an artifact of the method of mounting the sample in epoxy. As the epoxy cures, it shrinks and pulls the sample apart. Figures 4-6 and 4-7 show the results of SEM examination of these single cells. High-rnagnification SEM photographs showing the microstructures of the electrode layers are given in Figures 4-8 and 4-9.

During this reporting period, a batch of lanthanum manganite cathode powder was synthesized by solid state reaction. Powders produced by solid state reaction are expected to be relatively coarse and less sinterable. The objective was to use this powder to improve cathode porosity and modify cathode morphology. The solid state reaction preparation of the powder utilized the oxides, carbonates, or nitrates of La. Sr, and Mn as precursor materials. An aqueous slurry of the precursor materials was prepared and spray-dried. The spray-dried product was heated to decompose the nitrates and then calcined at elevated temperatures to complete the solid state formation of $\mathrm{Sr}$-doped $\mathrm{LaMnO}_{3}$. Figure 4-10 shows the morphology of the cathode powder prepared by the solid state process described above. For comparison, a SEM photograph of the HUA Associates powder currently used in this program is given in Figure 4-11. It is clearly seen that the two powders have quite different particle morphologies. The solid state reaction powder has a surface area of about $2.7 \mathrm{~m}^{2} / \mathrm{g}$ and a mean particle size of about 7 microns. This powder will be used in cathode formulations to modify cathode porosity and morphology. 


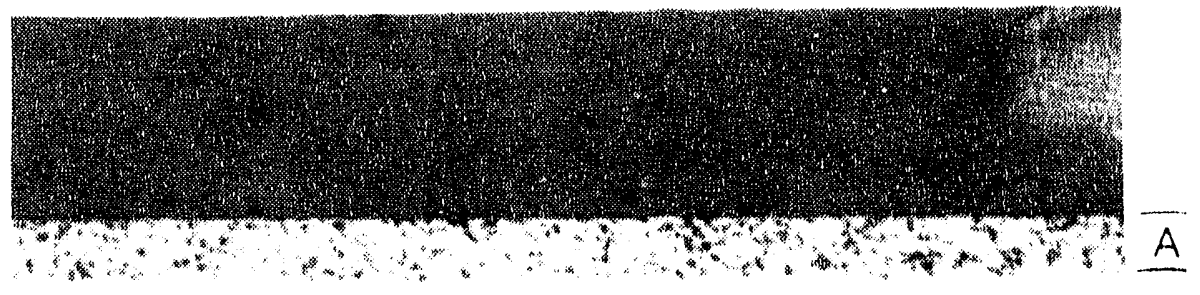

$E$

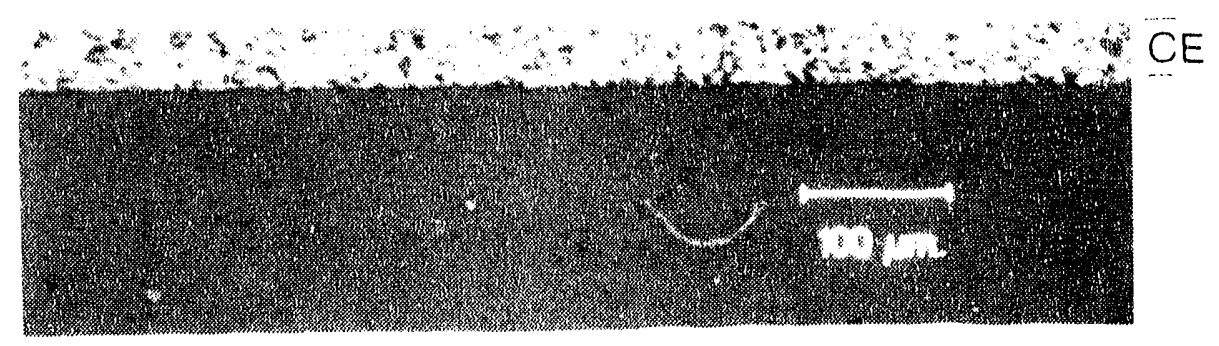

Figure 4-4. Polished Cross-Section of A:E:CE Single Cell (METC 16-08)

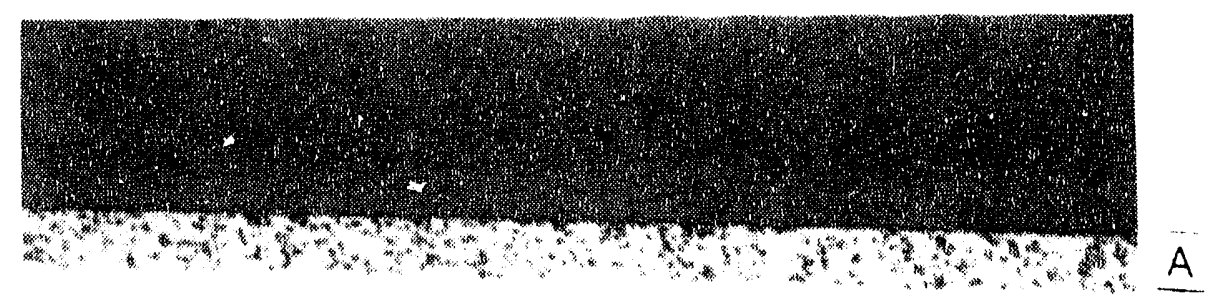

$E$

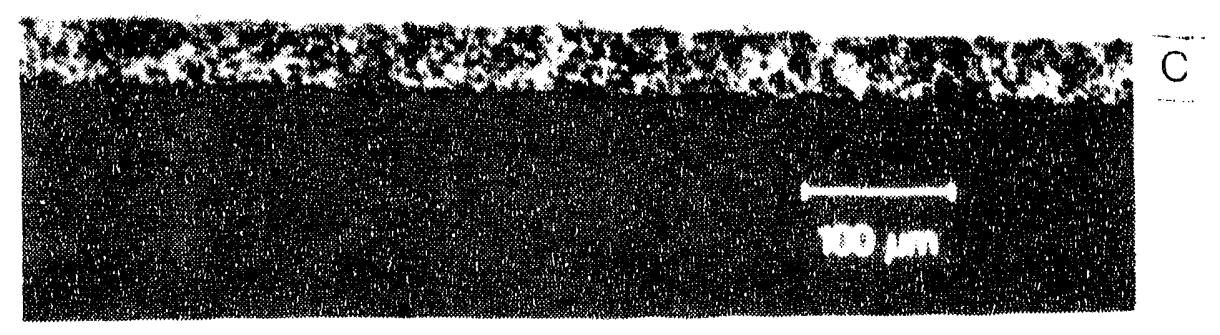

Figure 4-5. Polished Cross-Section of A:E:C Single Cell (METC 16-09)

88-61845(4)

Page 4-4 


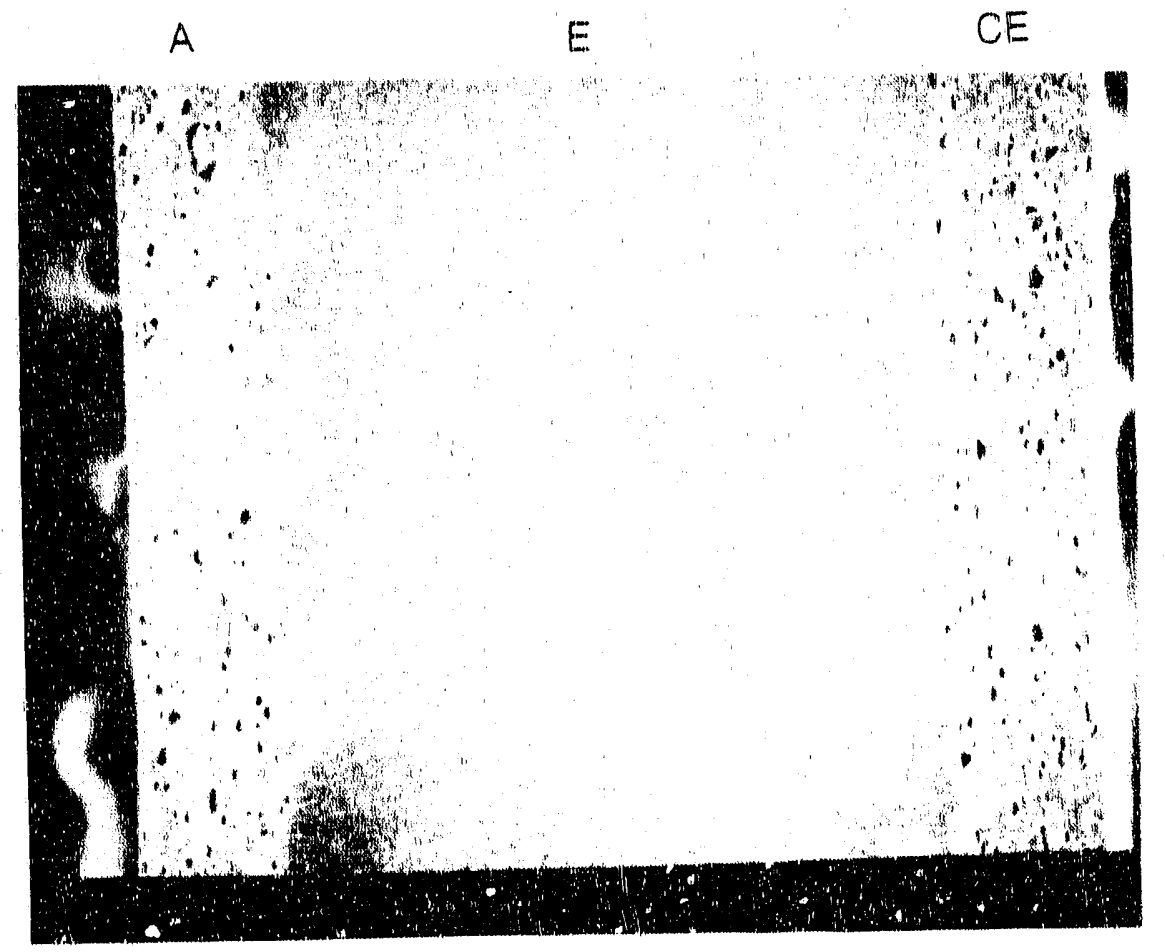

Figure 4-6. Fracture Surface of A:E:CE Single Cell (METC 16-08)

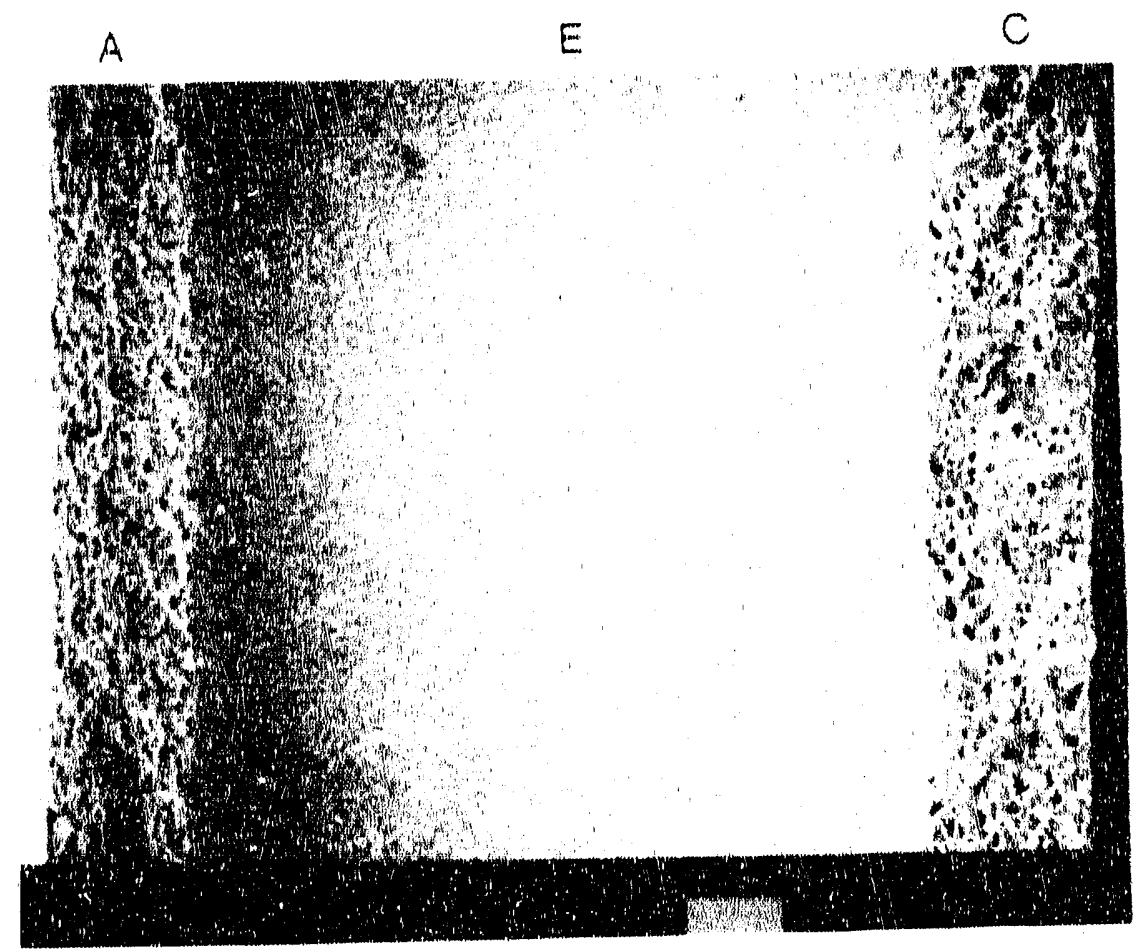

Figure 4-7. Fracture Surface of A:E:C Single Cell (METC 16-09) 


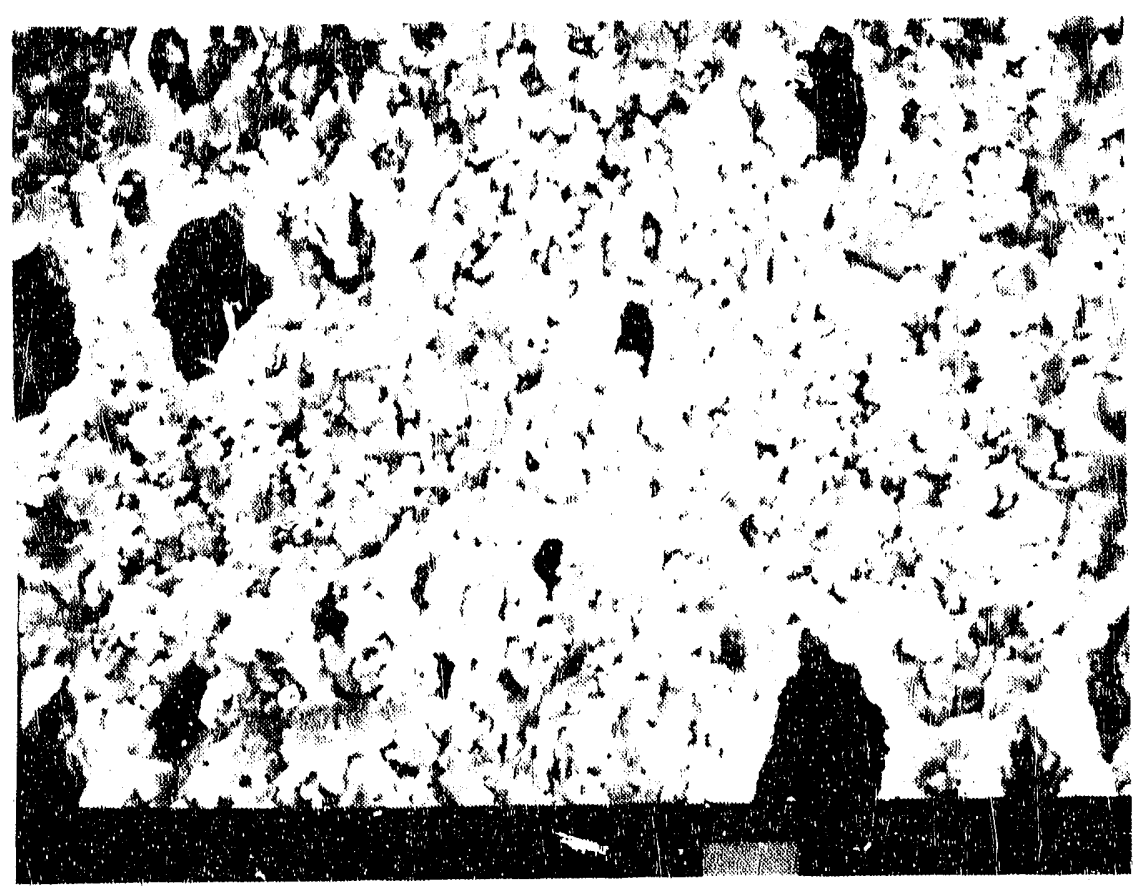

(A)

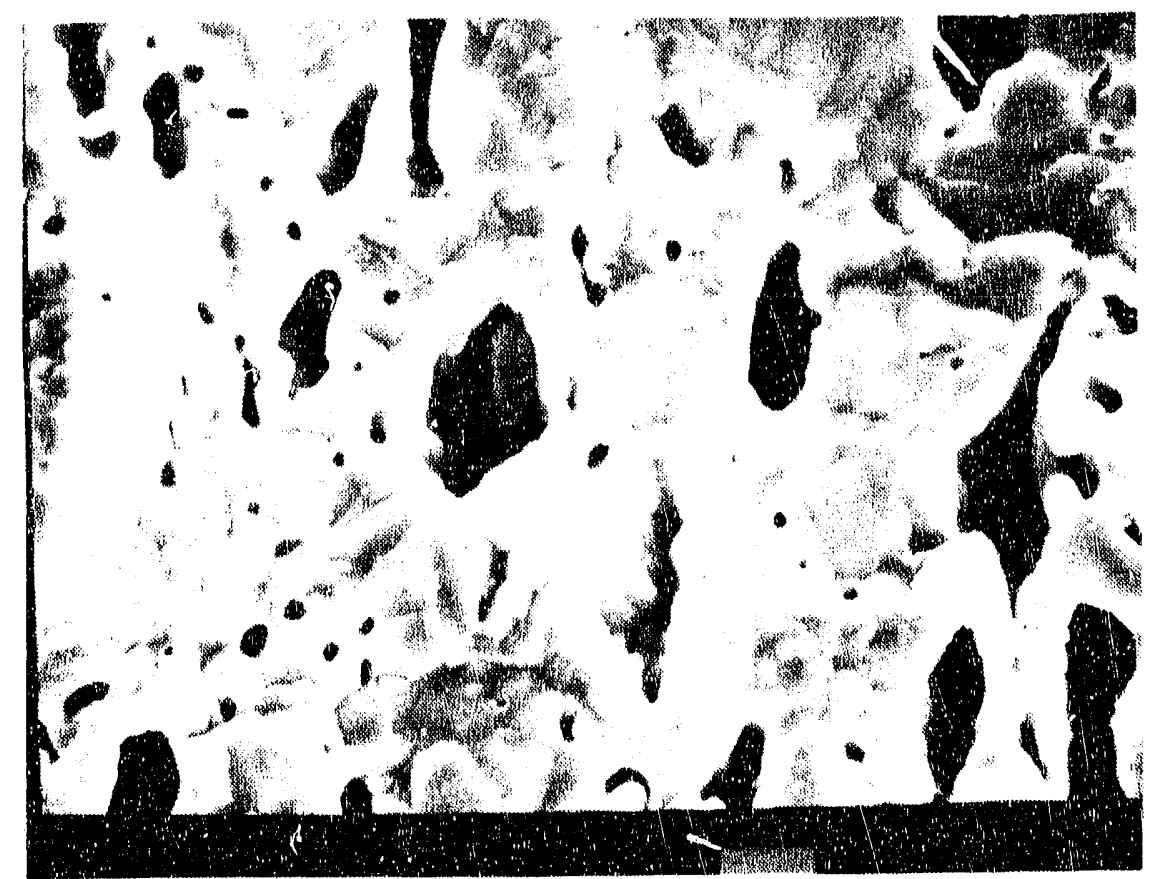

(B)

Figure 4-8. Scanning Electron Micrographs of

(A) Anode Layer

(B) Cathode/Electrolyte Intermediate Layer

of A:E:CE Single Cell (iv TTC 16-08)

$88-61845(4)$

Page 4-6 


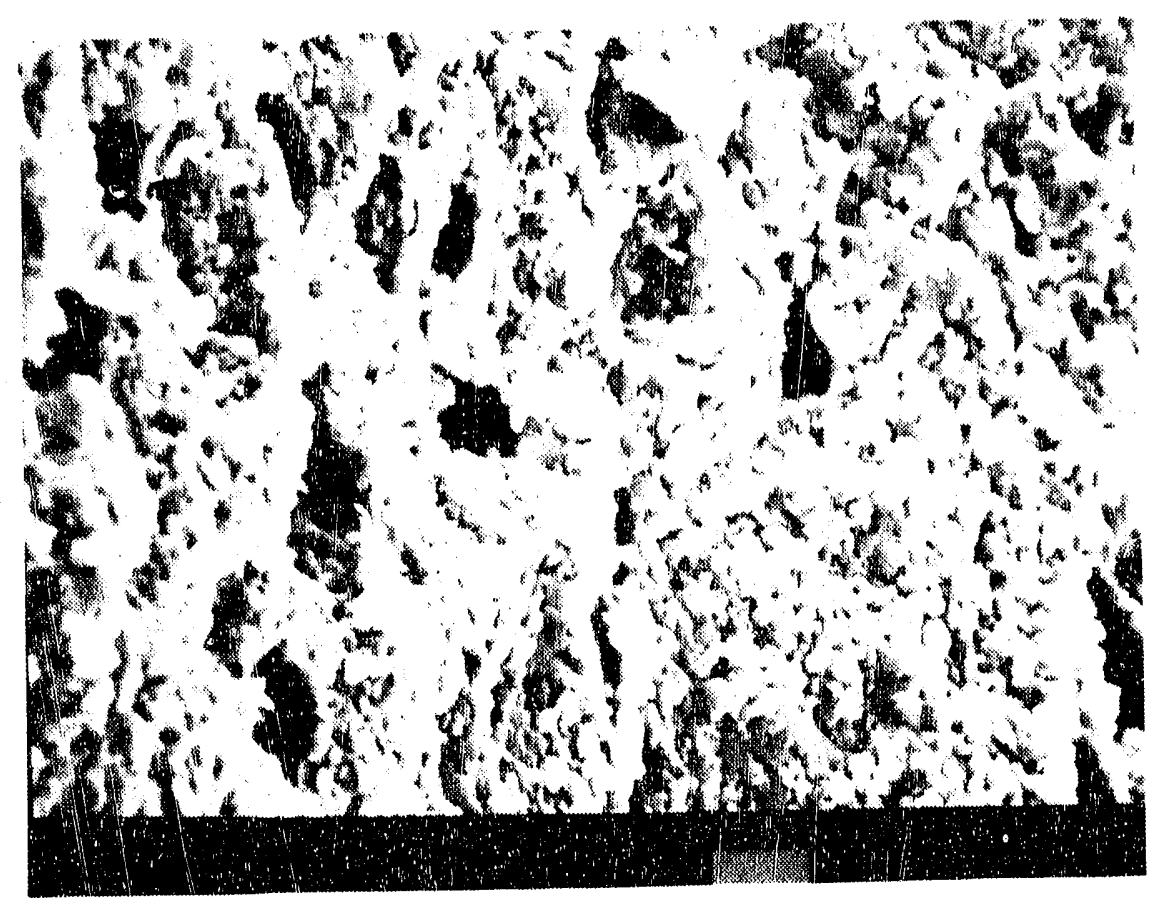

(A)

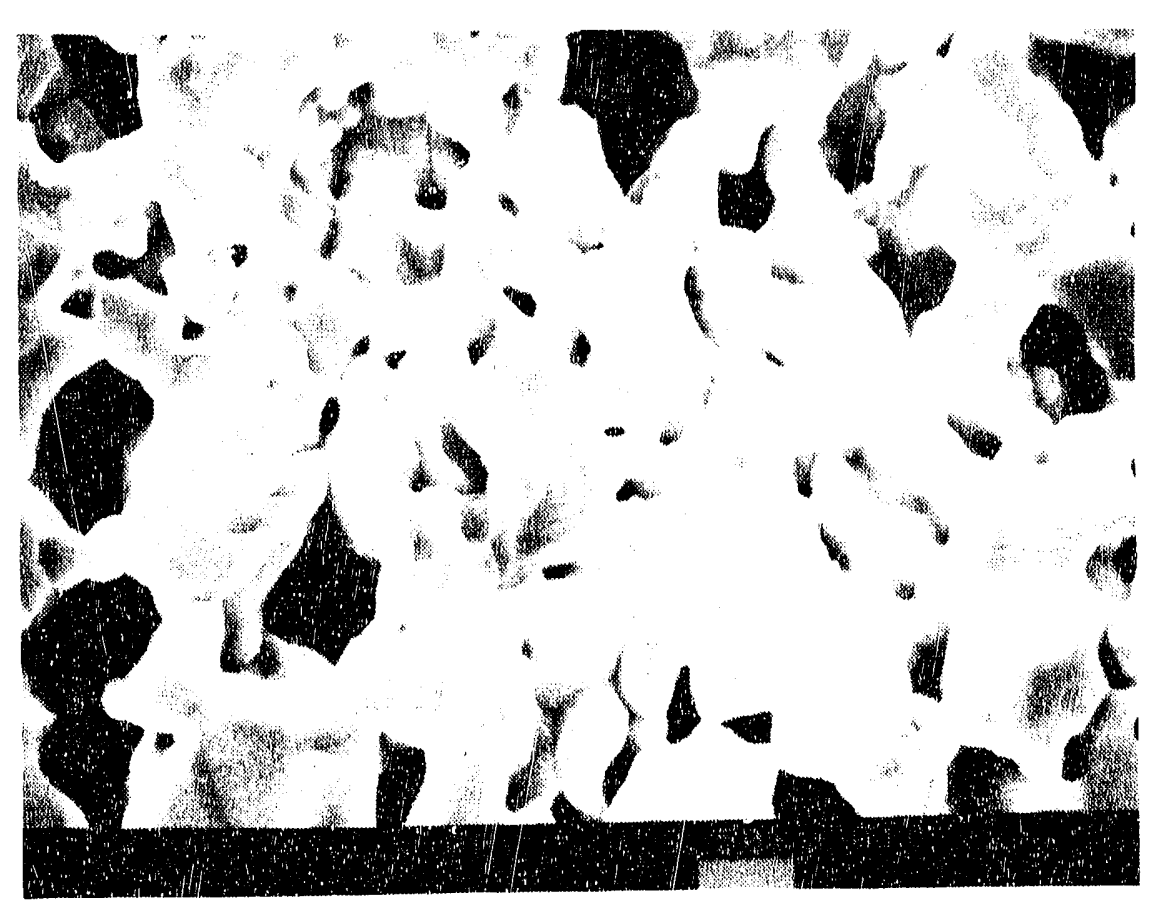

(B)

Figure 4-9. Scanning Electron Micrographs of
(A) Anode Layer
(B) Cathode Layer
of $A: E: C$ Single Cell (METC 16-09) 


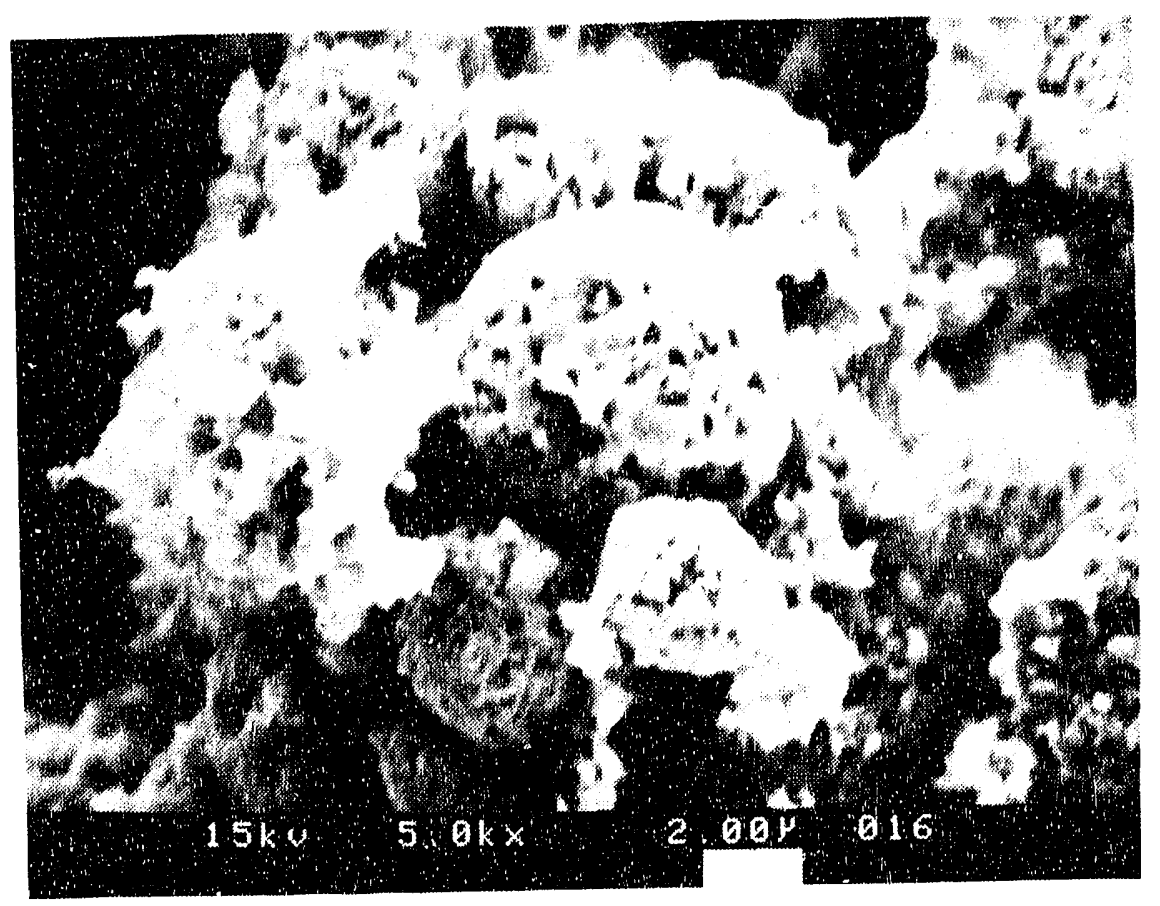

Figure 4-10. SEM Photograph of Sr-doped $\mathrm{LaMnO}_{3}$ Powder Prepared by Solid State Reaction

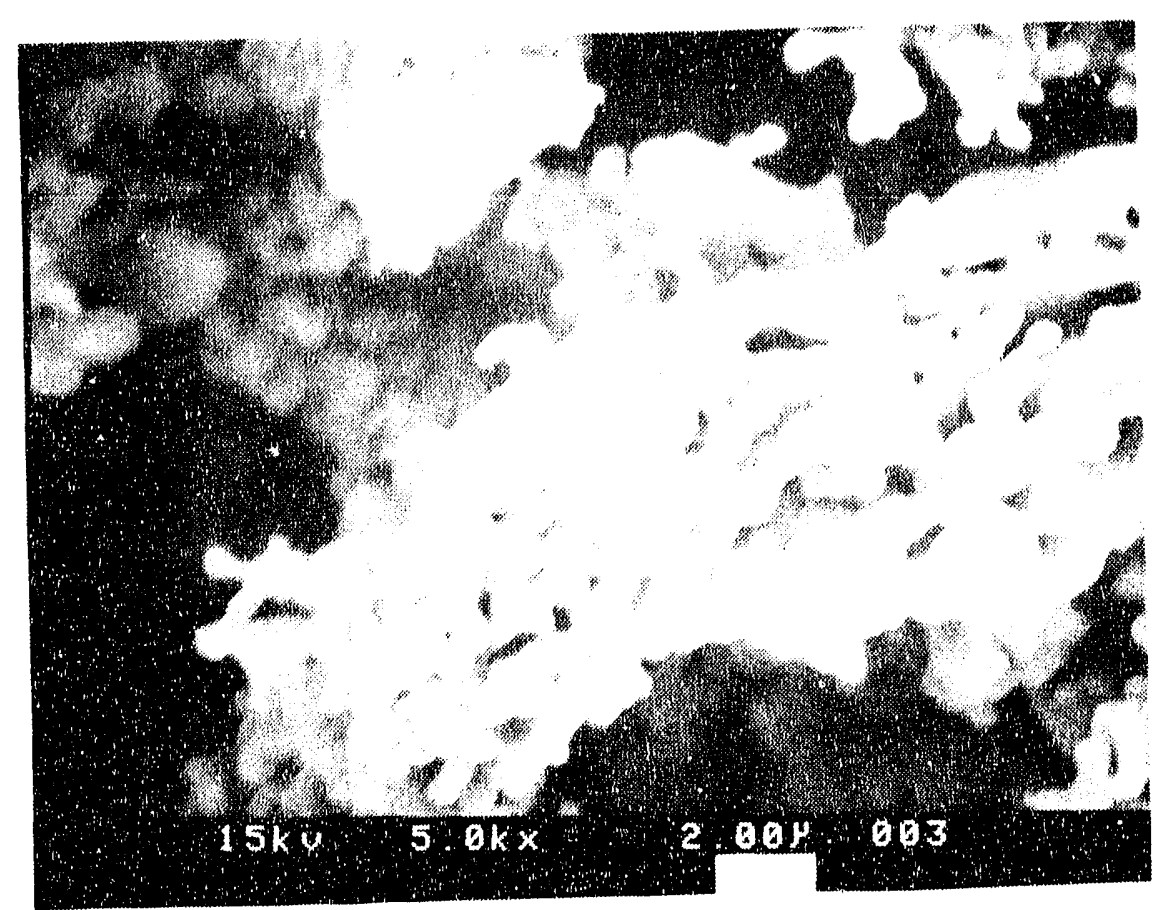

Figure 4-11. SEM Photograph of HUA Associates Sr-doped $\mathrm{LaMnO}_{3}$ Powder (Calcined at $1200^{\circ} \mathrm{C}, 5 \mathrm{hr}$ )

$88-61845(4)$

Page 4-8 


\subsection{CHARACTERIZATION}

A symmetrical cathode/electrolyte:electrolyte:cathode/electrolyte (CE:E:CE) composite (METC 16-14) and two symmetrical cathode:electrolyte:cathode (C:E:C) composites (METC 16-16 and 16-12) were studied. All of the composites were fabricated by similar processes except for METC 16-16 which was produced with solvent bonding between the layers before rolling. The interfacial resistances of the composites were measured by an established procedure using $A C$ impedance methods under a variety of gas composition and temperature conditions. The composites were studied in an oxidant mixture of $\mathrm{O}_{2}$ and $\mathrm{N}_{2}$. None of the complex impedance plots of the composites exhibited a Warburg component, which indicates that there is no mass transport hindrance in the electrodes. Post-test examination of the composites also indicated that sufficient porosity was present in the cathode layers to allow sufficient oxygen transport.

The effect of oxygen partial pressure on the interfacial resivtances of these three composites is shown in Figure 4-12, anci the effect of temperature on the interfacial resistances is shown in Figure 4-13. The interfacial resistance of a previously studied composite, METC 07-02, is also shown in these figures for comparison. It is clear that none of the composites studied this quarter performed as well as METC 07-02. From the standpoint of interfacial current distribution, one would expect that the CE:E:CE composite (METC 16-14) would perform simiiarly to the $C: C E: E: C E: C$ composite and better than the $C: E: C$ composite. Figures 4-12 and 4-13 show that the CE:E:CE composite did, in fact, perform better than the $C: E: C$ composite. However, the current data are insufficient to determine whether the differences between METC 16-14 and METC 07-02 are due to batch-to-batch variations or due to enhancernent of the performance by the dual cathode layers. The facts that both of the $C: E: C$ composites performed similarly indicates that solvent bonding does not significantly affuct the interfacial performance.

The interfacial resistances of the composites in air at $1000^{\circ} \mathrm{C}$ are: $0.0312 \mathrm{ohm}-\mathrm{cm}^{2}$ for METC $07-02,0.189 \mathrm{ohm}-\mathrm{cm}^{2}$ for METC 16-14, $0.536 \mathrm{ohm}-\mathrm{cm}^{2}$ for METC 16-16, and 0.378 ohm- $\mathrm{cm}^{2}$ for METC 16-12. This can be compared to a value of $0.154 \mathrm{ohm}-\mathrm{cm}^{2}$ for the interfacial resistance of a typical composite fabricated at Argome National Laboratory under the same conditions.

\subsection{STACK FABRICATION}

During the reporting period, two cross-flow stacks, ST1038 and ST1039, were fabricated. This trial fabrication attempts to gain experience in forming and firing crossflow stacks for this program.

The stacks were made from the same batches of materials used in the fabrication of single cells except for the anode batch. The zirconia from a new lot was also used to make a new anode batch, A-06199. This batch has a same formulation as A-09088 and A-11238 (used for making single cells) except that the powders used in A-06199 were prepared at a different time and the zirconia powder came from a different lot. The new zirconia powder was calcined and milled to tailor its surface area and particle size distribution. Some of the properties of A-06199 are listed in Table 4-2. Comparing these properties with those of the 


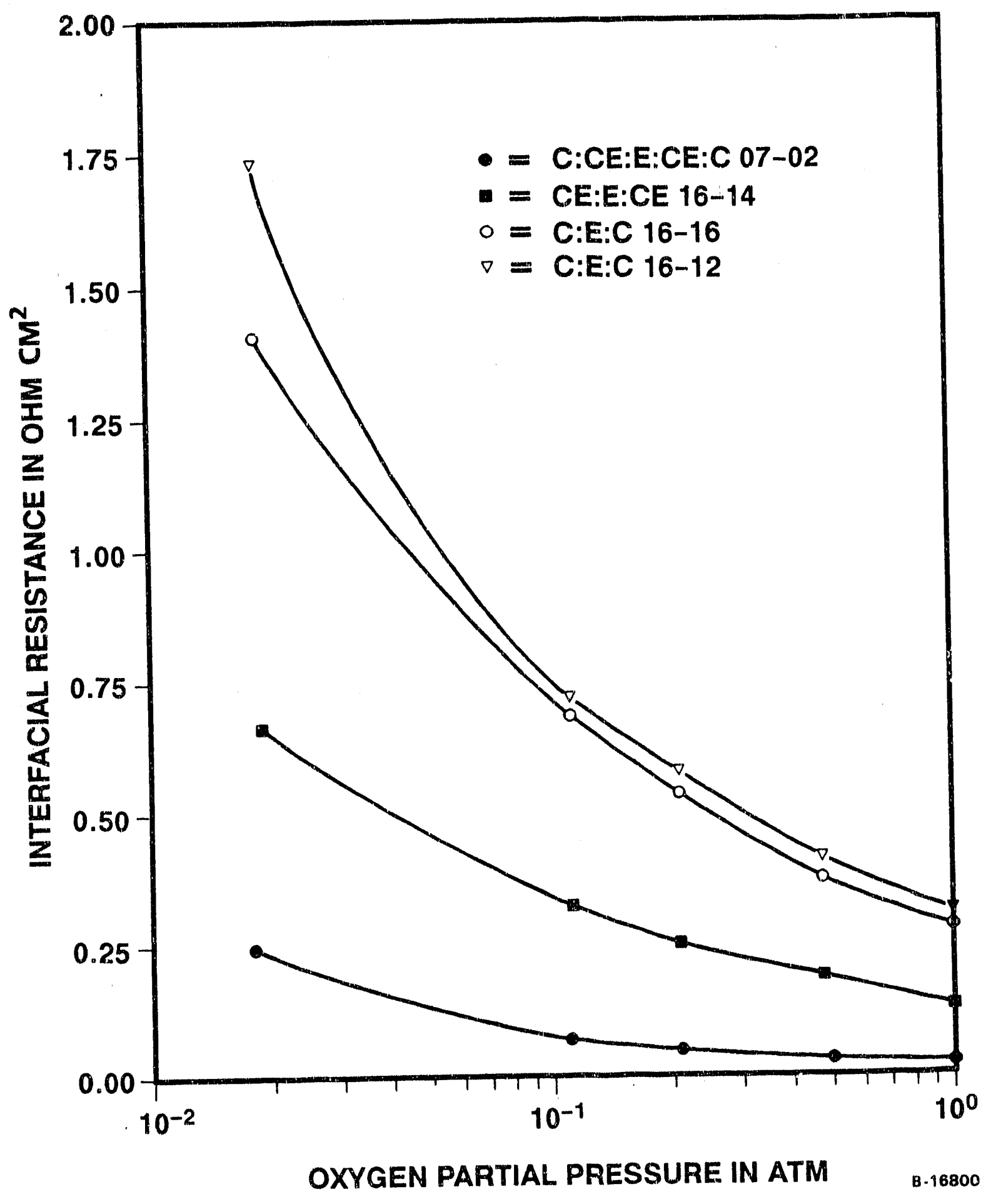

Figure 4-12. Interfacial Area Specific Resistance of C:CE:E:CE:C Composite (METC 07-02), CE:E:CE Composite (METC 16-14), C:E:C Composites (METC 16-16 and 16-12) vs. Oxygen Partial Pressure at $1000^{\circ} \mathrm{C}$ with Balance of Gas Being $\mathrm{N}_{2}$. 


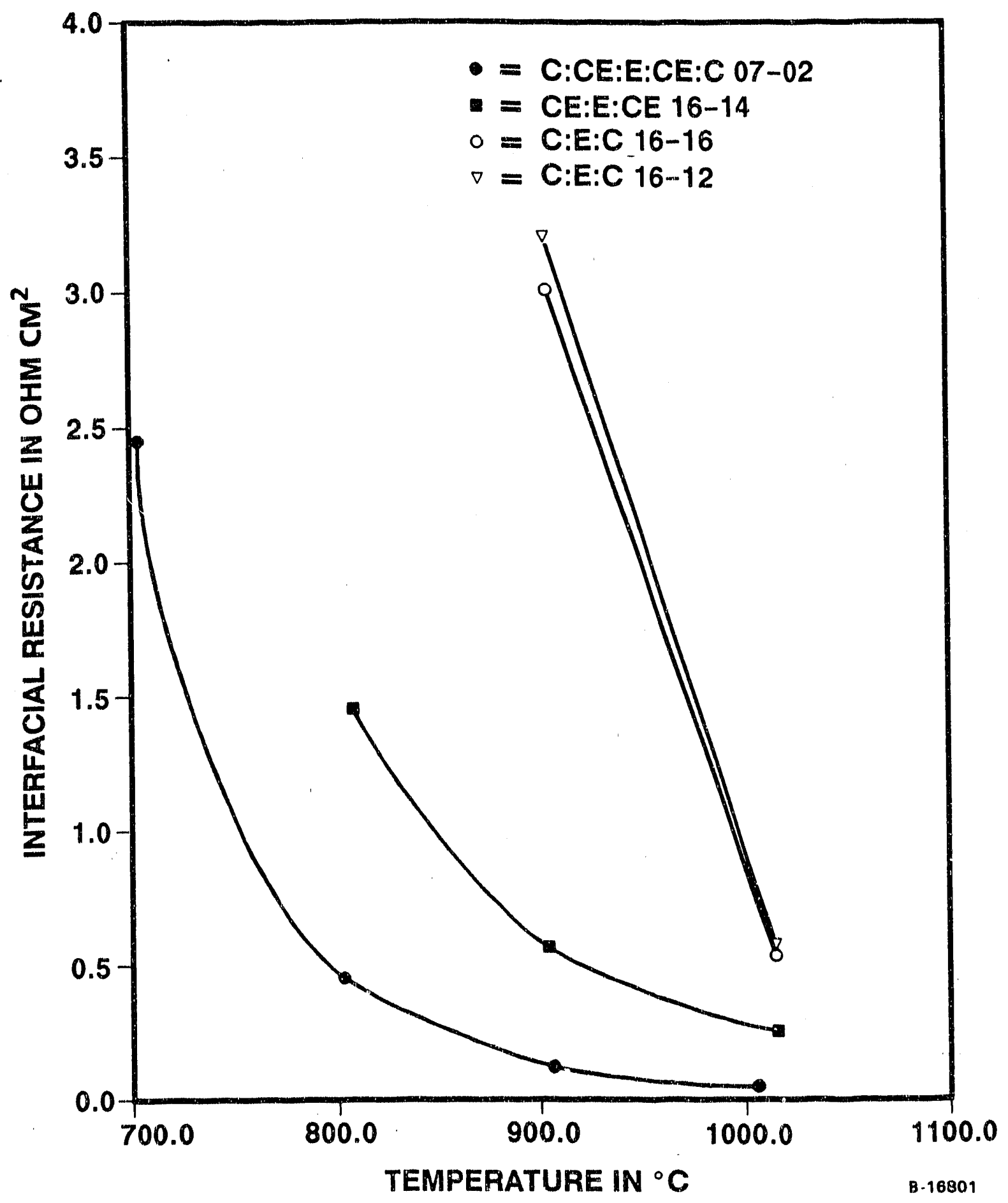

Figure 4-13. Interfacial Area Specific Resistance of C:CE:E:CE:C Composite (METC 07- 2), CE:E:CE Composite (METC 16-14), C:E:C

Composites (METC 16-16 and 16-12) vs. Temperature in Air. 
other anode batches (also listed in Table 4-2), it is seen that A-06199 has a slightly higher shrinkage and density. These variances most likely are due to the different zirconia lot used in making A-06199.

\begin{tabular}{|c|c|c|c|c|c|c|}
\hline \multicolumn{7}{|c|}{ TABLE 4-2 } \\
\hline Batch & Sample & \multicolumn{2}{|c|}{ Shrinkage } \\
Number & Number & Dianeter & Thickness & Density & $\begin{array}{c}\text { Percent } \\
\text { Theoretical }\end{array}$ & $\begin{array}{c}\text { Total } \\
\text { Porosity }\end{array}$ \\
\hline A-06199 & M21-01 & 20 & 30.15 & 4.72 & 73.96 & 26.04 \\
& M21-02 & 21 & 29.63 & 4.79 & 75.07 & 24.93 \\
& M21-03 & 21 & 30.66 & 4.81 & 75.44 & 24.56 \\
& M21-04 & 21 & 29.32 & 4.83 & 75.67 & 24.33 \\
& Average & 20.75 & 29.94 & 4.79 & 75.04 & 24.96 \\
\hline A-09088 & M09-04 & 19 & 26.56 & 4.61 & 72.19 & 27.81 \\
& M09-05 & 19 & 25.98 & 4.56 & 71.51 & 28.49 \\
& M09-06 & 19 & 27.50 & 4.61 & 72.28 & 27.72 \\
& Average & 19 & 26.68 & 4.59 & 71.99 & 28.01 \\
\hline A-11238 & $160-01$ & 21 & 13.91 & 4.74 & 74.35 & 25.65 \\
& $160-02$ & 20 & 32.14 & 4.62 & 72.36 & 27.64 \\
& $160-03$ & 21 & 30.57 & 4.62 & 72.46 & 27.54 \\
& $160-04$ & 20 & $30.9<$ & 4.60 & 72.07 & 27.93 \\
& Average & 20.5 & 26.89 & 4.64 & 72.81 & 27.19 \\
\hline
\end{tabular}

The cross-flow stacks were fabricated using the same procedure that has been done in earlier work. First, tapes of either anode or cathode were compression molded into corrugations. Care was taken to ensure no tearing of the tape. After forming, the top die is removed and a flat composite tape is bonded to the exposed peaks of the pressed tape (note that for end plates flat anode and cathode tapes are used). The assembly is then carefully lifted off of the bottom die and then cut to the desired size. Cutting is done using a scalpel and a straight-edge. The tapes can be sliced easily with a sharp instrument, but care must be taken to ensure a clean cut. After the assemblies have been cut they can be bonded one on top of the other to form a stack.

The above described fabrication procedure was used to construct the two cross-flow stacks, ST1038 and ST1039. In both stacks, there are five flat layers and four corrugations, giving a two cell stack. The flat layers at the top and bottom surfaces of the stack are composed solely of cathode and anode, respectively. The flat layer in the middle of both stacks are trilayer tape containing the interconnect sandwiched between anode and cathode. The other two flat layers in the stacks are trilayer tape that contain the electrolyte sandwiched between anode and catode. The corrugations in the stacks consist of either anode or cathode only. The green-state thickness of the tapes used in the stacks were about 0.013 inch-0.015 inch. 
Photographs of stacks ST1038 and ST1039 are shown in Figure 4-14. Both stacks had a $2 \times 2$ inch plan area, as shown in Figure 4-15. The discoloration present on the top surface of ST1039 (Figure 4-15) is due to the lighting used in the photograph. The surface was flat and clean.

Figure 4-16 shows a side of ST1039 after a piece of the stack for optical microscopic examination had been cut off. The cathode "channels" run parallel to the plane of the photograph while the anode "channels" run perpendicular. The different components of the flat layers are visible in the photograph. The gaps in right side of the cathode corrugations resulted from cutting the stack and not from fabrication. The piece that was cut from ST1039 was then hardened using a proprietary method while still in the green-state, and then mounted and polished. Figure 4-17 is a micrograph of a section of this piece. The flat layer at the top of the photograph contains interconnect while the bottom layer contains the electrolyte. The cathode in the top layer has a large thickness due to the cut being along the "valley" of a cathode corrugation bonded to the interconnect-containing flat layer. The bonding of the anode corrugation with flat layer is excellent as seen from Figure 4-17. The uniformity is beneficial to the corrugation being processed without cracking. Figure 4-18 is a micrograph of the whole piece cut from ST1039. The uniformity of the anode corrugations across the whole piece can be seen. The cathode corrugation in the middle was not cut precisely along the bond between the corrugation and the flat layer (also see Figure 4-16) resulting in the diagonal line below the upper anode corrugation.

Stacks ST1038 and ST1039 are being processed. The results will be reported in the next quarterly report. 


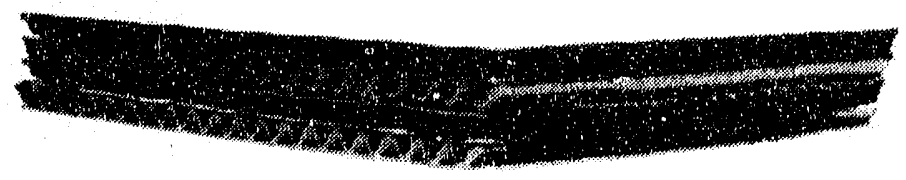

(a)

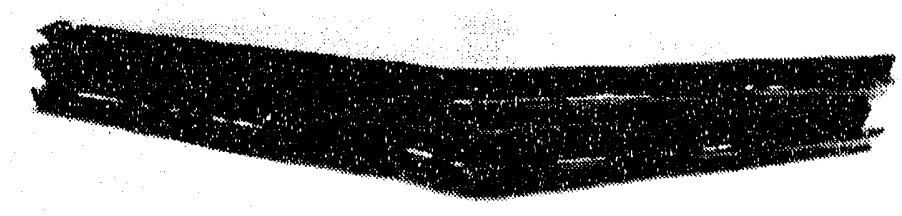

(b)

Figure 4-14. Edge-view of Stack ST1038 and Stack ST1039. Top Corrugation is Cathode. 


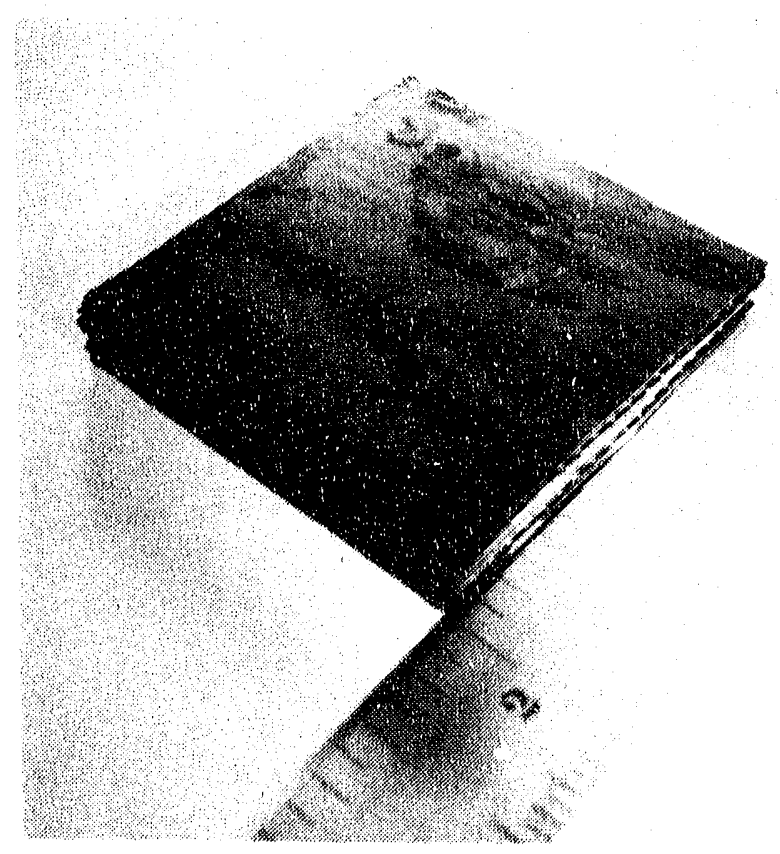

Figure 4-15. Top-view of Stack ST1039. Top Corrugation is Cathode.

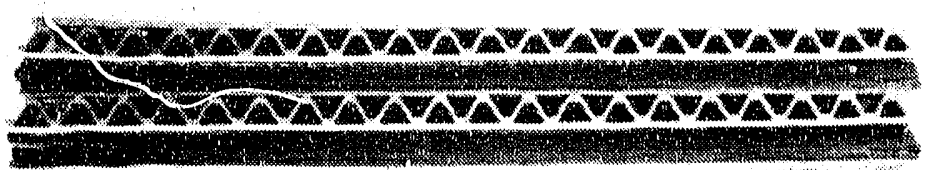

Figure 4-16. Side-view of Stack ST1039

$88-61845(4)$ 


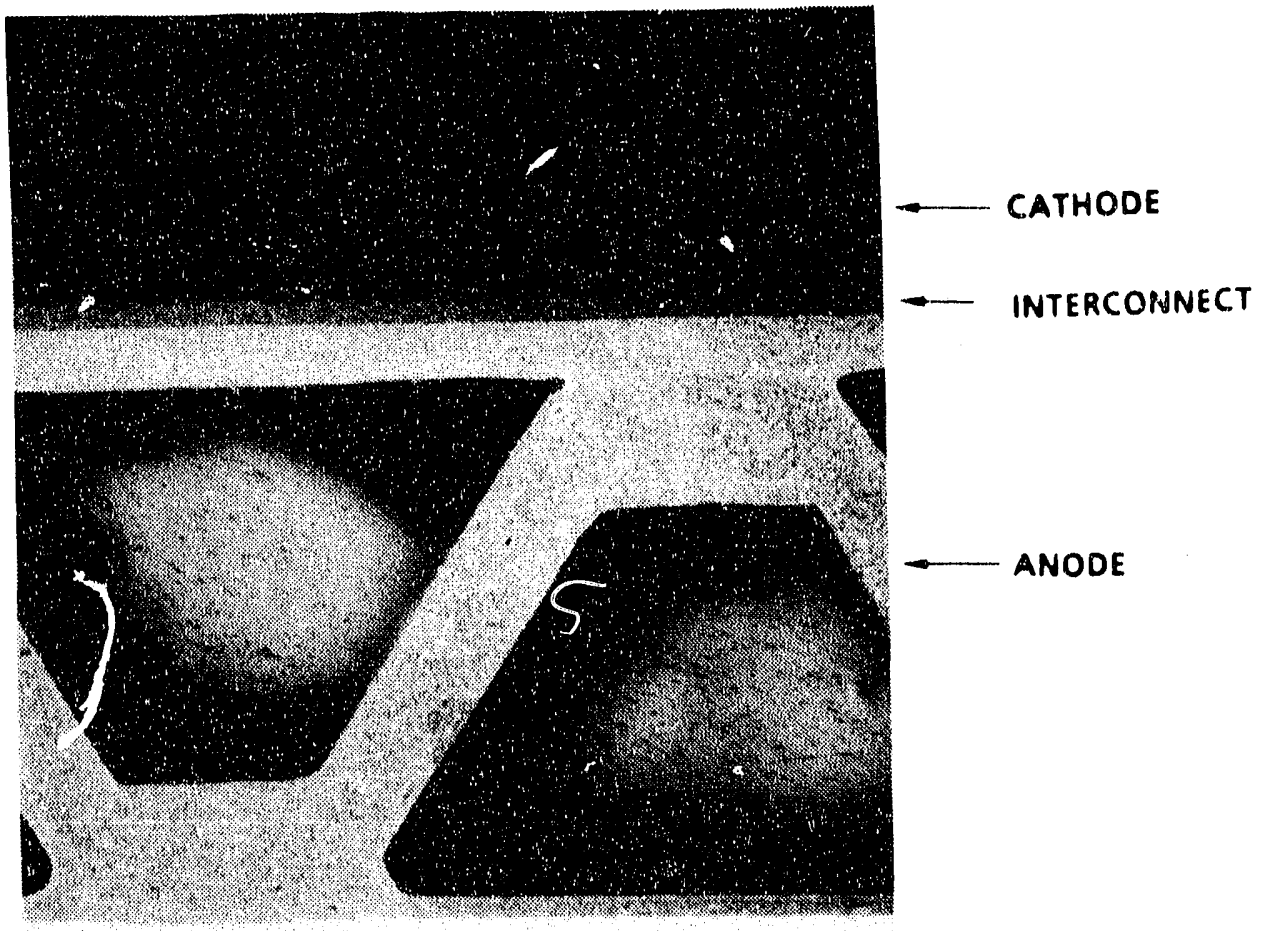

ELECTROLYTE
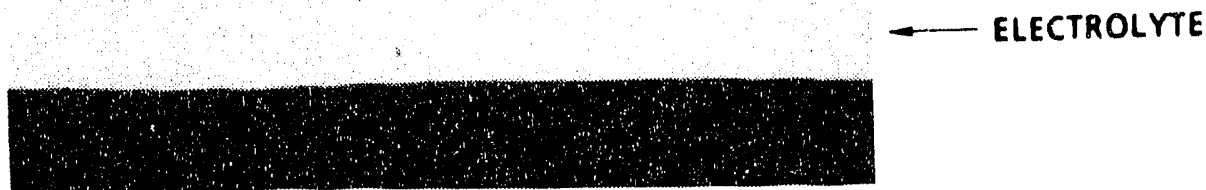

Figure 4-17. Micrograph of Cross Section of Stack ST1039 (green) showing an Anode Corrugation. (Magnification 40X) 

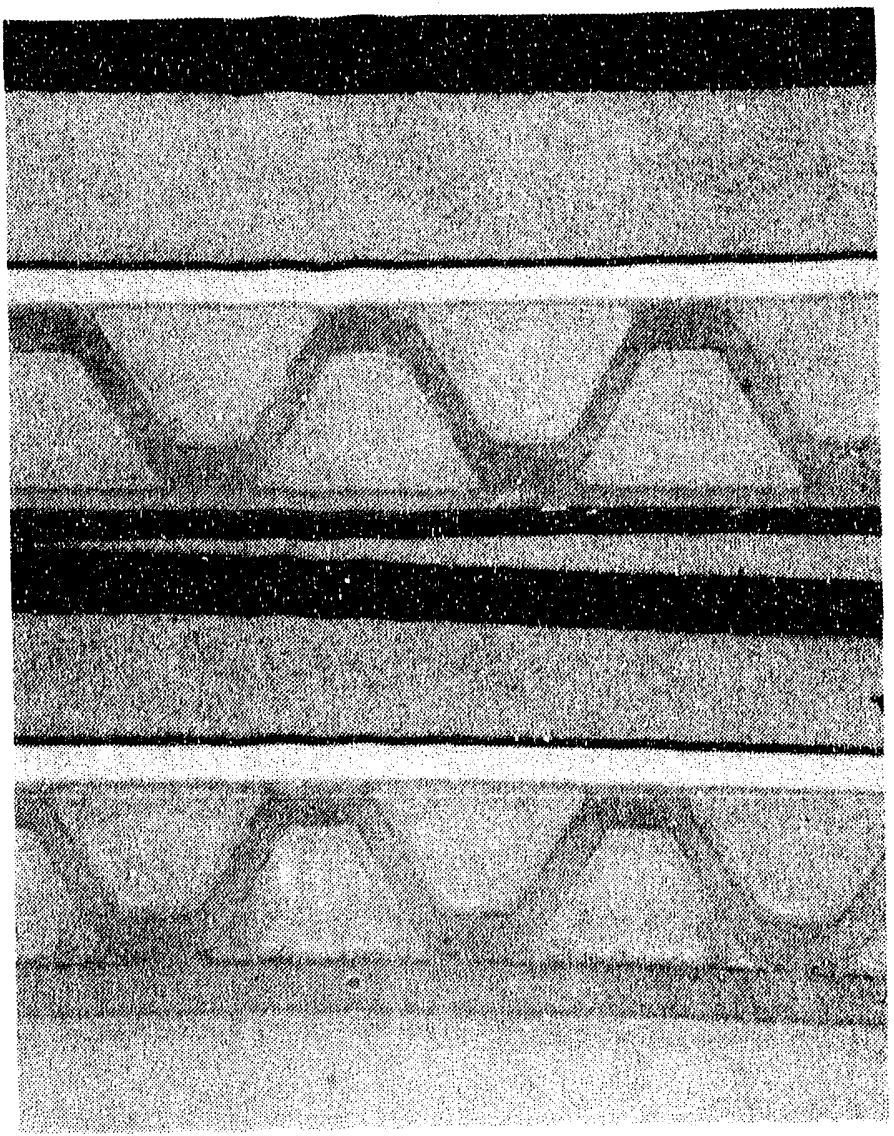

Figure 4-18. Micrograph of Stack ST1039 showing Whole CrossSection. (Magnification 14X) 


\section{PERFORMANCE ON COAL GAS}

\subsection{OBJECTIVE}

The objectives of this task are:

(i) To evaluate the performance of the MSOFC on simulated coal-derived gases.

(ii) To study the effect of sulfur contaminants on MSOFC performance, establish sulfur tolerance limit, and establish reversibility of sulfur contamination.

\subsection{PERFORMANCE TESTING}

Performance testing of several single cells was carried out during this reporting period. The schematic diagram of the single cell test apparatus is shown in Figure 5-1. The apparatus consists of a cell holder made of stabilized zirconia tube. The single cell with $\mathrm{Pt}$ current collectors attached is cemented to the end of the zirconia tube. A reducing atmosphere is maintained inside the tube. A zirconia extension tube was cemented onto the cathode side of the cell in a similar manner. Platinum wires were spot welded to the platinum current collectors for electrical connections to the cell. A platinum- $10 \%$ rhodium wire was also conriented to the cell to act as a thermocouple. A reference electrode consisting of a platinum paste electrode on the outside of the zirconia gas manifold tube near the cell was added to the apparatus. The reference electrode allowed for electrochemical studies to be conducted on either the anode or cathode separately. The zirconia tube with the cell was

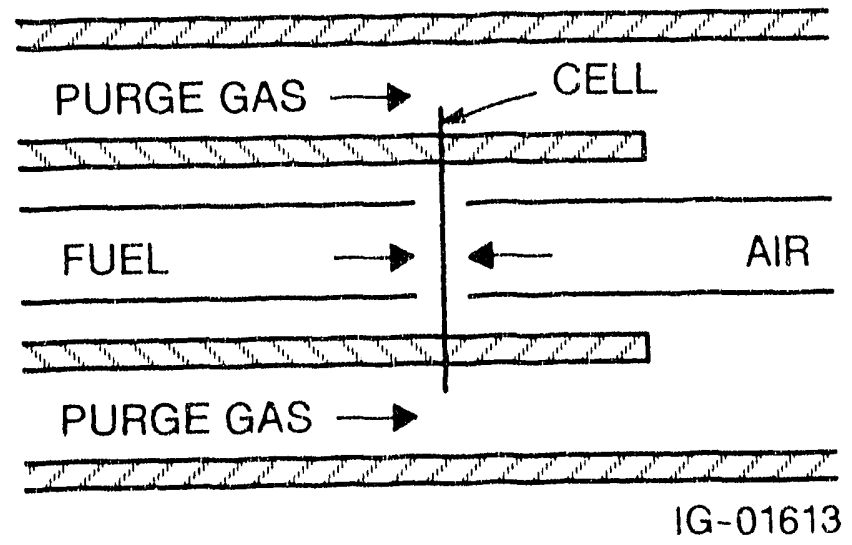

Figure 5-1. Diagram of MSOFC Single Cell Test Apparatus 
then placed inside a larger diameter alumina tube. The two atmospheres were $e$ stablished by flowing fuel down a small feeder tube inside the zirconia tube and flowing oxidant down a small feeder tube inside the alumina tube shown in Figure 5-1. Both feeder tubes were terminated within a centimeter of the cell. A purge gas (helium) flowed outside the zirconia tube. Three cells (METC 10-03, 18-03, 18-05) were tested in $5 \% \mathrm{H}_{2}$ in $\mathrm{He}\left(0.15 \% \mathrm{H}_{2} \mathrm{O}\right) /$ Air, $97 \% \mathrm{H}_{2}-3 \% \mathrm{H}_{2} \mathrm{O} / \mathrm{A}$ ir, $97 \% \mathrm{H}_{2}-3 \% \mathrm{H}_{2} \mathrm{O} /$ oxygeri. Additional testing was performed on cells METC 18-03 and 18-05. Cell 18-03 was subjected to a constant current endurance test using a gas composition of $67 \% \mathrm{H}_{2}, 22 \% \mathrm{CO}, 11 \% \mathrm{H}_{2} \mathrm{O}$ typical of a synthetic reformate. Cell 18-05 was tested in anode gas mixtures containing 100 and 400 ppm hydrogen sulfide. Table 5-1 contains the fabrication details for the three cells.

\begin{tabular}{|c|c|c|c|}
\hline \multicolumn{4}{|c|}{$\begin{array}{c}\text { TABLE 5-1 } \\
\text { SINGLE CELL FABRICATION DETAILS }\end{array}$} \\
\hline Cell Number & $\begin{array}{l}\text { Cell Construction } \\
A: E: C E: C \text { Ratio }\end{array}$ & $\begin{array}{c}\text { Firing Temperature } \\
\text { and Time }\end{array}$ & Material Batch \\
\hline $\begin{array}{l}\text { METC } \\
10-03\end{array}$ & $1: 5: 1: 1$ & $\begin{array}{c}1400^{\circ} \mathrm{C} \\
1 \mathrm{hr}\end{array}$ & $\begin{array}{c}A-09088 \\
E-08108 \\
C E-08228 \\
C-08238\end{array}$ \\
\hline $\begin{array}{l}\text { METC } \\
18.03\end{array}$ & $1: 5: 1: 1$ & $\begin{array}{l}1350^{\circ} \mathrm{C} \\
0.5 \mathrm{hr}\end{array}$ & $\begin{array}{c}A-11238 \\
E-02148 \\
C E-08228 \\
C-08238\end{array}$ \\
\hline $\begin{array}{l}\text { METC } \\
18.05\end{array}$ & $1: 5: 1: 1$ & $\begin{array}{c}1350^{\circ} \mathrm{C} \\
0.5 \mathrm{hr}\end{array}$ & $\begin{array}{c}A-09088 \\
E-08108 \\
C E-08228 \\
C-08238\end{array}$ \\
\hline
\end{tabular}

Plots of cell voltage vs current density for each cell are included in Figures 5-2 through 5-4. Table 5--2 sumirnarizes the cell resistance data.

The measured current densities in $97 \% \mathrm{H}_{2}-3 \% \mathrm{H}_{2} \mathrm{O}$ fuel at approximately $600 \mathrm{mV}$ for the three cells are listed below.

\begin{tabular}{|c|c|c|}
\hline Cell Number & Air & Oxygen \\
\hline METC 10.03 & $200 \mathrm{~mA} / \mathrm{cm}^{2}$ at $619 \mathrm{mV}$ & $800 \mathrm{~mA} / \mathrm{cm}^{2}$ at $603 \mathrm{mV}$ \\
\hline METC 18.05 & $375 \mathrm{~mA} / \mathrm{cm}^{2}$ at $617 \mathrm{mV}$ & $700 \mathrm{~mA} / \mathrm{cm}^{2}$ at $614 \mathrm{mV}$ \\
\hline METC $18-03$ & $100 \mathrm{~mA} / \mathrm{cm}^{2}$ at $629 \mathrm{mV}$ & $125 \mathrm{~mA} / \mathrm{cm}^{2}$ at $634 \mathrm{mV}$ \\
\hline
\end{tabular}




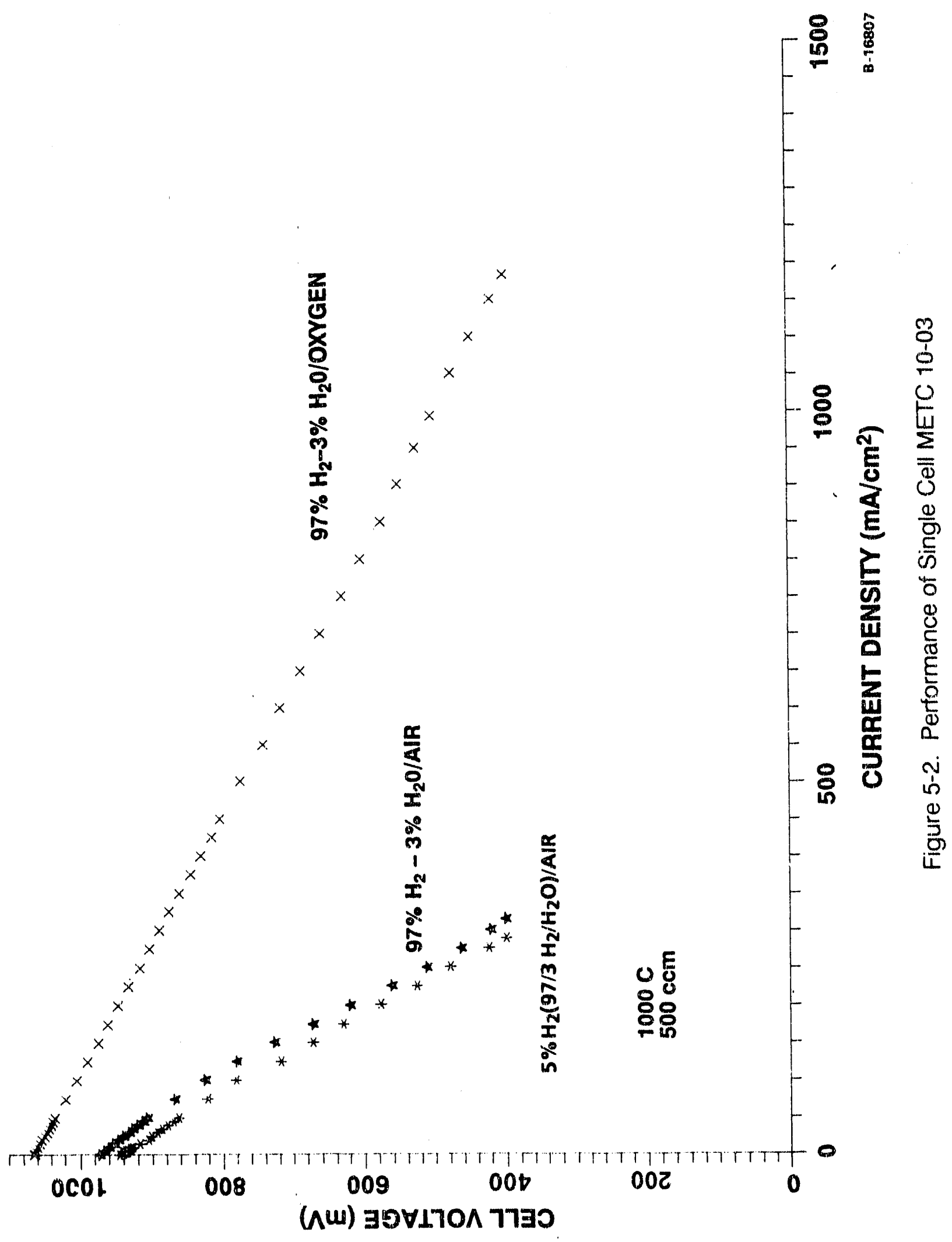

89-61845(4)

Page 5-3 


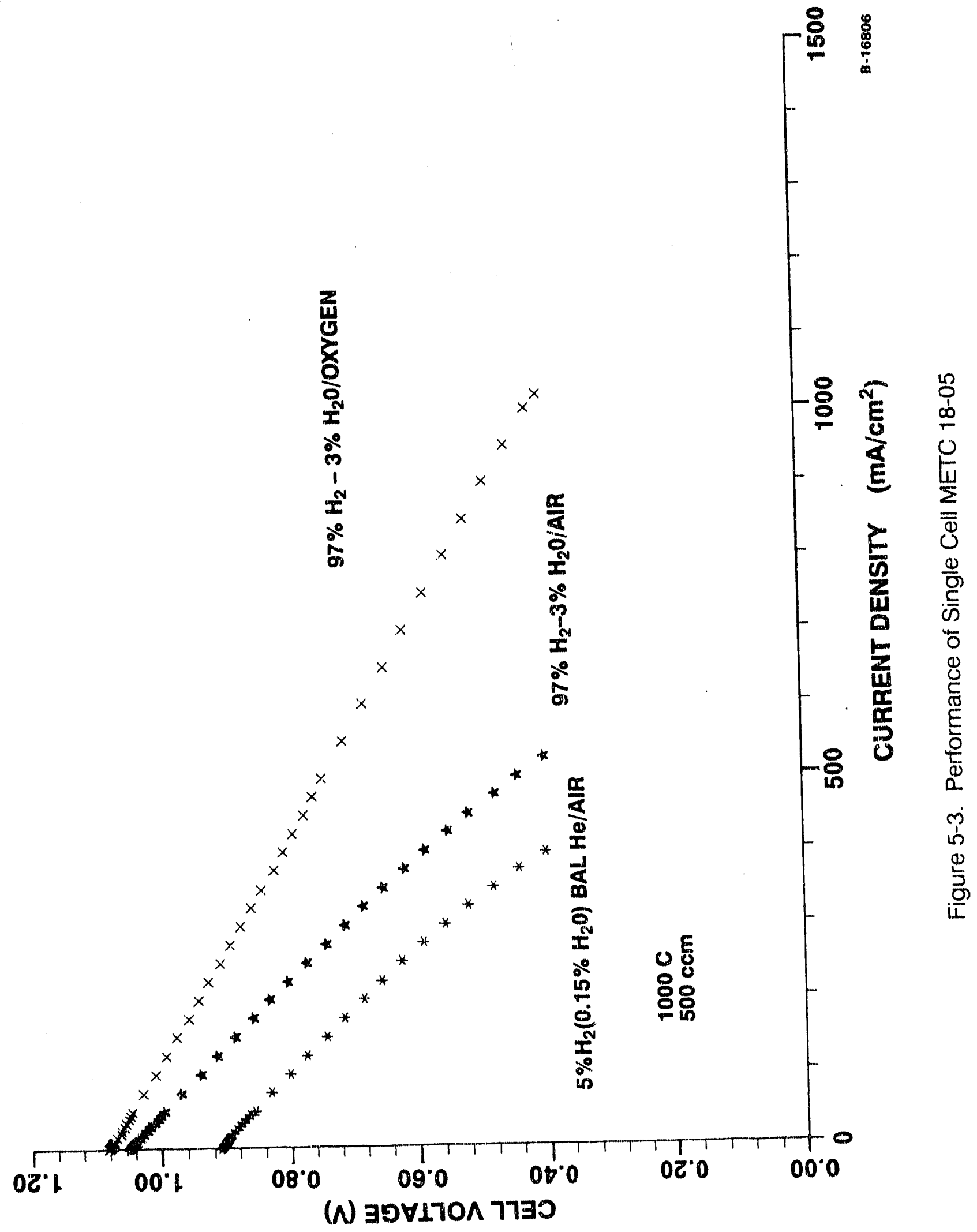

89-61845(4) 


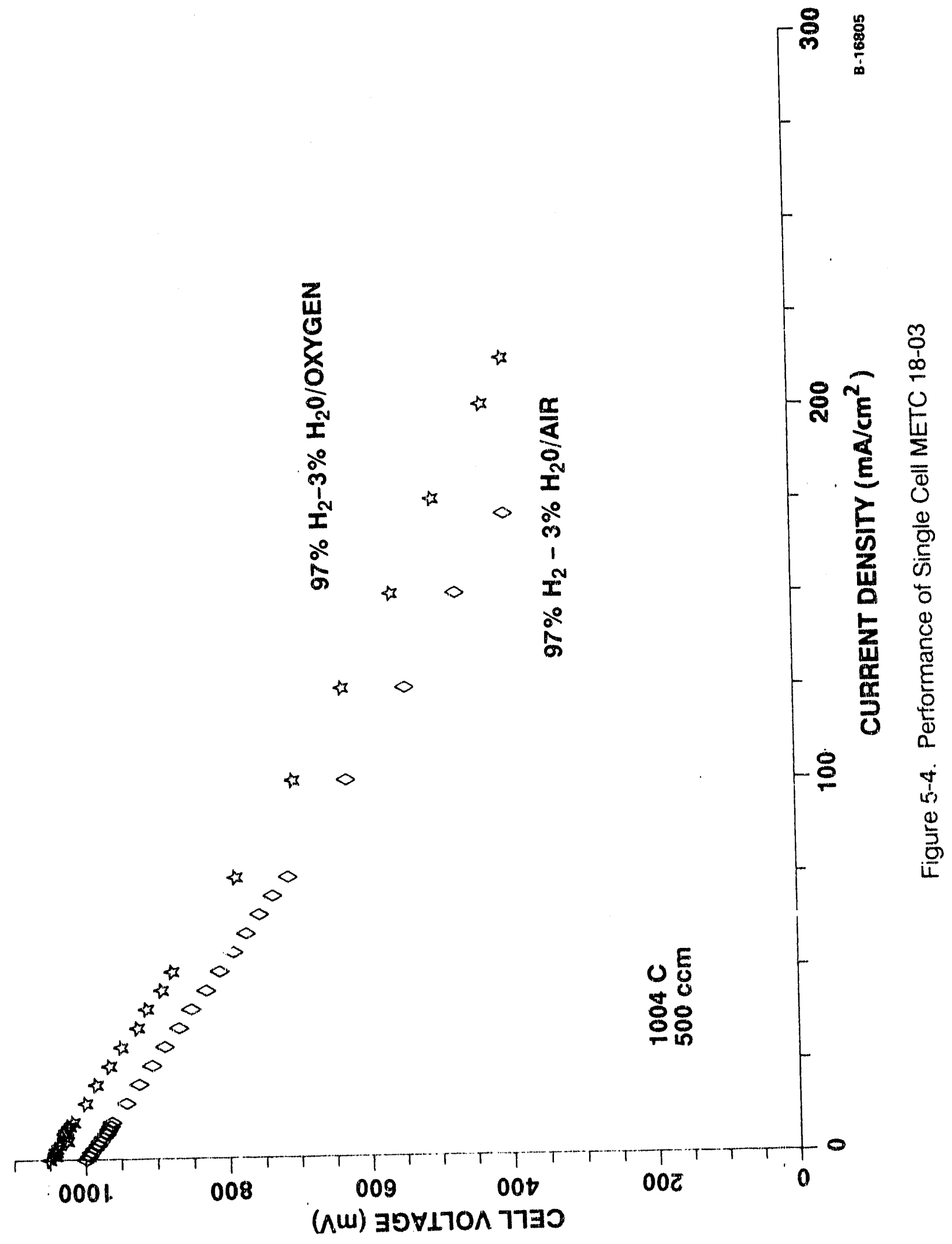

89-61845(4)

Page 5-5 


\begin{tabular}{|c|c|c|c|c|c|}
\hline & SUMMARY OF CEL & $\begin{array}{l}\text { LE 5-2 } \\
\text { ESISTAN }\end{array}$ & S AT 100 & $0^{\circ} \mathrm{C}$ & \\
\hline & & & & Resistance & \\
\hline $\begin{array}{c}\text { Cell } \\
\text { Number }\end{array}$ & Gas Composition & $\begin{array}{c}\text { Open } \\
\text { Circuit } \\
\text { Voltage } \\
\text { (mV) }\end{array}$ & $\begin{array}{l}\text { Ohmic } \\
\text { (ohms } \\
\left.\mathrm{cm}^{2}\right)\end{array}$ & $\begin{array}{c}\text { Interfacial } \\
\text { (ohms } \\
\mathrm{cm}^{2} \text { ) }\end{array}$ & $\begin{array}{c}\text { Total Cel } \\
\text { (ohms } \\
\mathrm{cm}^{2} \text { ) }\end{array}$ \\
\hline $\begin{array}{l}\text { METC } \\
10-03\end{array}$ & $\begin{array}{l}5 \% \mathrm{H}_{2}-\mathrm{He} / \text { Air } \\
\mathrm{H}_{2}\left(97 / 3 \mathrm{H}_{2} / \mathrm{H}_{2} \mathrm{O}\right) / \text { Air } \\
\mathrm{H}_{2}\left(97 / 3 \mathrm{H}_{2} / \mathrm{H}_{2} \mathrm{O}\right) / \text { Oxygen }\end{array}$ & $\begin{array}{c}945 \\
972 \\
1065\end{array}$ & $\begin{array}{l}0.24 \\
0.25 \\
0.24\end{array}$ & $\begin{array}{l}1.42 \\
1.08 \\
0.38\end{array}$ & $\begin{array}{l}1.660 \\
1.330 \\
0.620\end{array}$ \\
\hline $\begin{array}{l}\text { METC } \\
18-05\end{array}$ & $\begin{array}{l}5 \% \mathrm{H}_{2}-\mathrm{He} / \mathrm{Air} \\
\mathrm{H}_{2}\left(97 / 3 \mathrm{H}_{2} / \mathrm{H}_{2} \mathrm{O}\right) / \text { Air } \\
\mathrm{H}_{2}\left(97 / 3 \mathrm{H}_{2} / \mathrm{H}_{2} \mathrm{O}\right) / \text { Oxygen }\end{array}$ & $\begin{array}{l}910 \\
1051 \\
1082\end{array}$ & $\begin{array}{l}0.31 \\
0.31 \\
0.31\end{array}$ & $\begin{array}{l}0.72 \\
0.81 \\
0.46\end{array}$ & $\begin{array}{l}1.036 \\
1.113 \\
0.766\end{array}$ \\
\hline $\begin{array}{l}\text { METC } \\
18-03\end{array}$ & $\begin{array}{l}\mathrm{H}_{2}\left(97 / 3 / \mathrm{H}_{2} / \mathrm{H}_{2} \mathrm{O} / \text { Air }\right. \\
\mathrm{H}_{2}\left(97 / 3 \mathrm{H}_{2} / \mathrm{H}_{2} \mathrm{O}\right) / \text { Oxygen }\end{array}$ & $\begin{array}{l}999 \\
1051\end{array}$ & - & $\overline{-}$ & $\begin{array}{l}3.740 \\
3.220\end{array}$ \\
\hline
\end{tabular}

Cell 10-03 and 18-05 were fabricated from identical material batches. Cell 10-03 was sintered at $1400^{\circ} \mathrm{C} / 1$ hour and Cell $18-05$ was sintered at $1350^{\circ} \mathrm{C} / 0.5$ hour. The performance and cell resistance data are similar for the two cells. Cell 18-03 was fabricated with different anode and electrolyte batches and sintered at $1350^{\circ} \mathrm{C} / 0.5$ hours. The decreased performance of cell 18-03 may be related to the different material batches used. More cell testing is needed to determine the specific cause of the decreased performance.

in addition to the standard performance tests in $97 \% \mathrm{H}_{2}-3 \% \mathrm{H}_{2} \mathrm{O} / \mathrm{Air}, 97 \% \mathrm{H}_{2}-3 \%$ $\mathrm{H}_{2} \mathrm{O}$ /oxygen, cell 18-03 was subjected to an endurance test using a synthetic reformate gas $\left(67 \% \mathrm{H}_{2}-22 \% \mathrm{CO}-11 \% \mathrm{H}_{2} \mathrm{O}\right)$ as the fuel. The test was conducted by first recording the cell voltage at $75 \mathrm{~mA} / \mathrm{cm}^{2}$ in $97 \% \mathrm{H}-3 \% \mathrm{H}_{2} \mathrm{O} /$ Air. After 8 hours the anode gas was switched to $67 \% \mathrm{H}_{2}-22 \% \mathrm{CO}-11 \% \mathrm{H}_{2} \mathrm{O}$. The cell voltage was monitored for an additional 36 hours. At the end of that time period, the fuel gas was changed back to $97 \% \mathrm{H}_{2}-3 \% \mathrm{H}_{2} \mathrm{O}$ and the cell experienced reactant gas cross over. The test was terminated as a result of this failure. The voltage vs time data is plotted in Figure 5-5. One can see from the plot that the cell voltage did not change significantly with the reformate gas. A $100 \mathrm{mV}$ performance decay was observed over the $45 \mathrm{hr}$ test.

\subsection{INFLUENCE OF SULFUR CONTAMINANTS ON PERFORMANCE}

Performance testing in gas mixtures containing 100 and $400 \mathrm{ppm} \mathrm{H}_{2} \mathrm{~S}$ was conducted on the third day of testing of cell 18-05. Cell performance in $\mathrm{H}_{2}(97 / 3) /$ air on day 3 had decayed $200 \mathrm{mV}$ at $300 \mathrm{~mA} / \mathrm{cm}^{2}$ relative to initial performance (Figure 5-6). The 


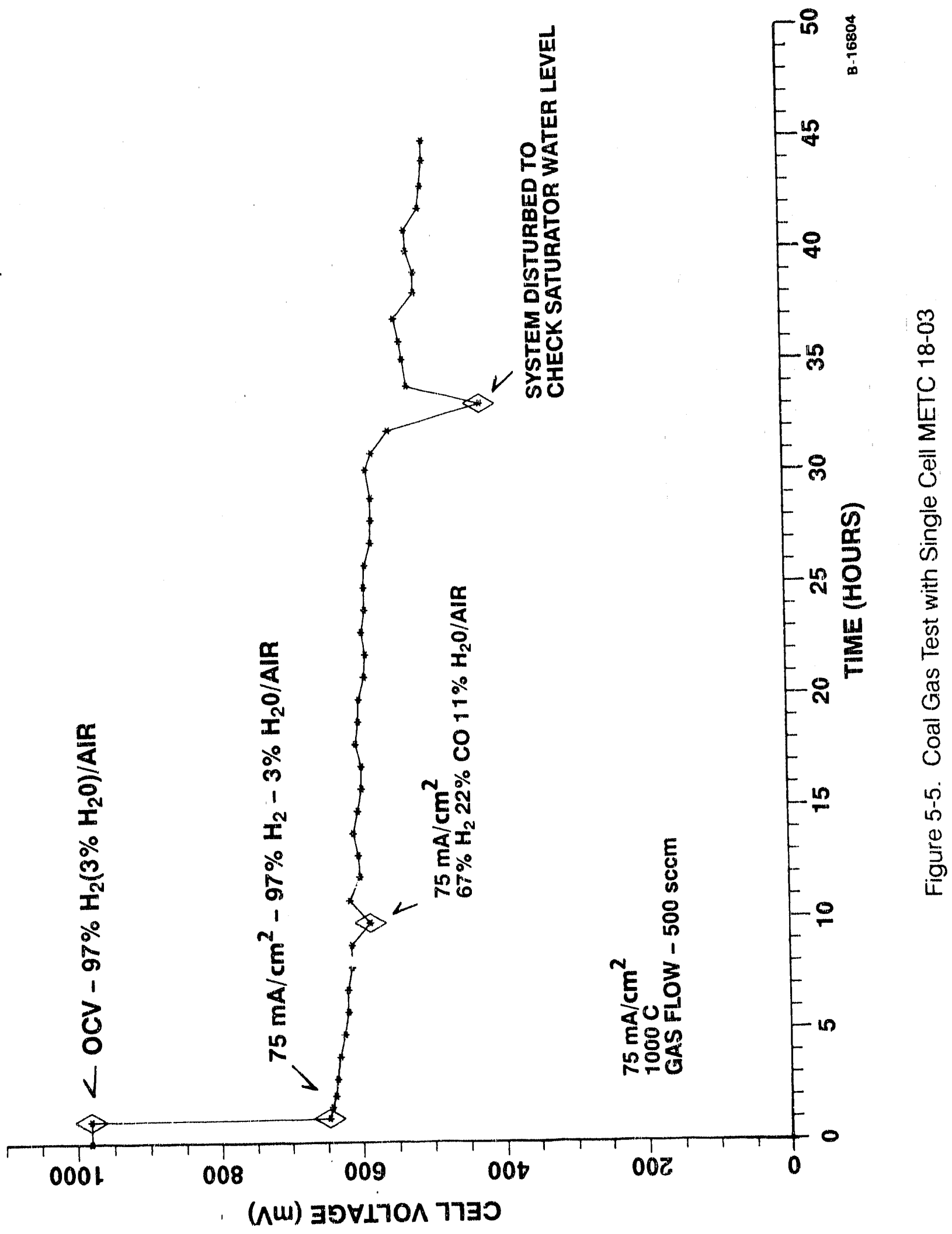




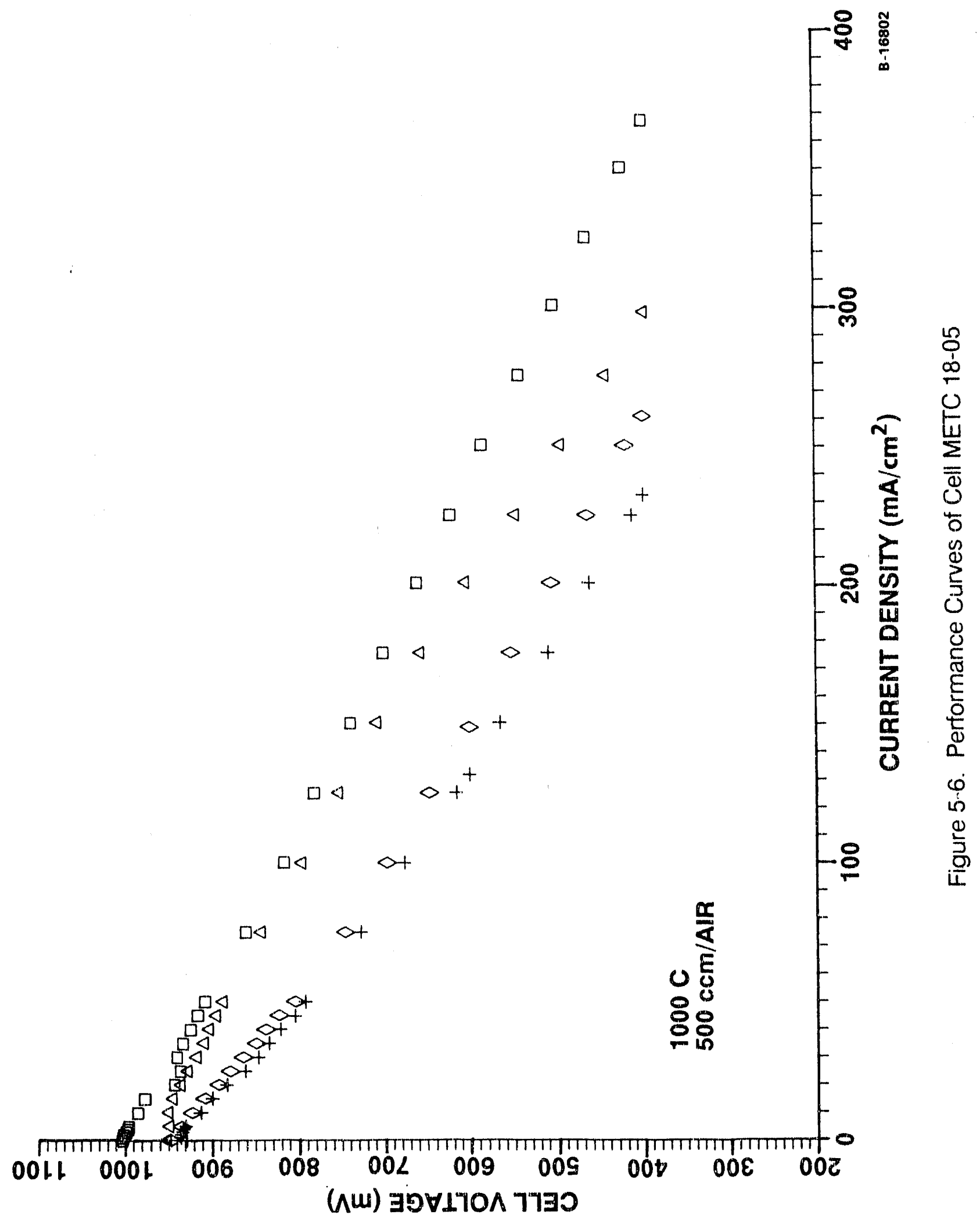


introduction of $\mathrm{H}_{2} \mathrm{~S}$ to the anode gas resulted in a further decrease in performance. The 100 and $400 \mathrm{ppm}$ sulfur voltage-current data as well as the performance on sulfur free anode gas before and after the sulfur test are plotted in Figure 5-7. Conclusions could not be drawn from the sulfur testing on Cell 18-05 due to the large performance decay observed in $97 \% \mathrm{H}_{2}-3 \% \mathrm{H}_{2} \mathrm{O} /$ air prior to the addition of sulfur. Further testing with presence of sulfur in the fuel will be carried out. 


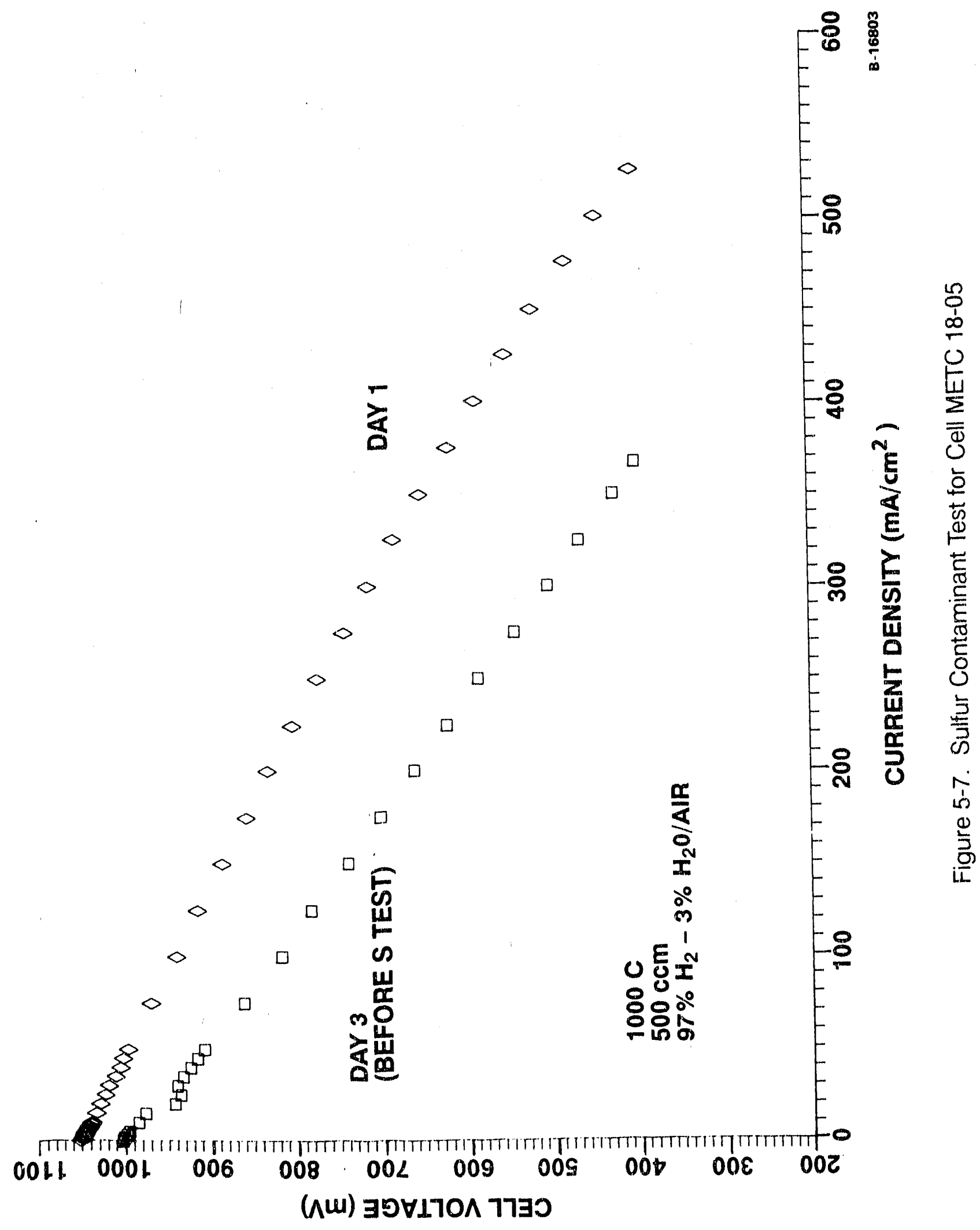

89-61845(4)

Page 5-10 

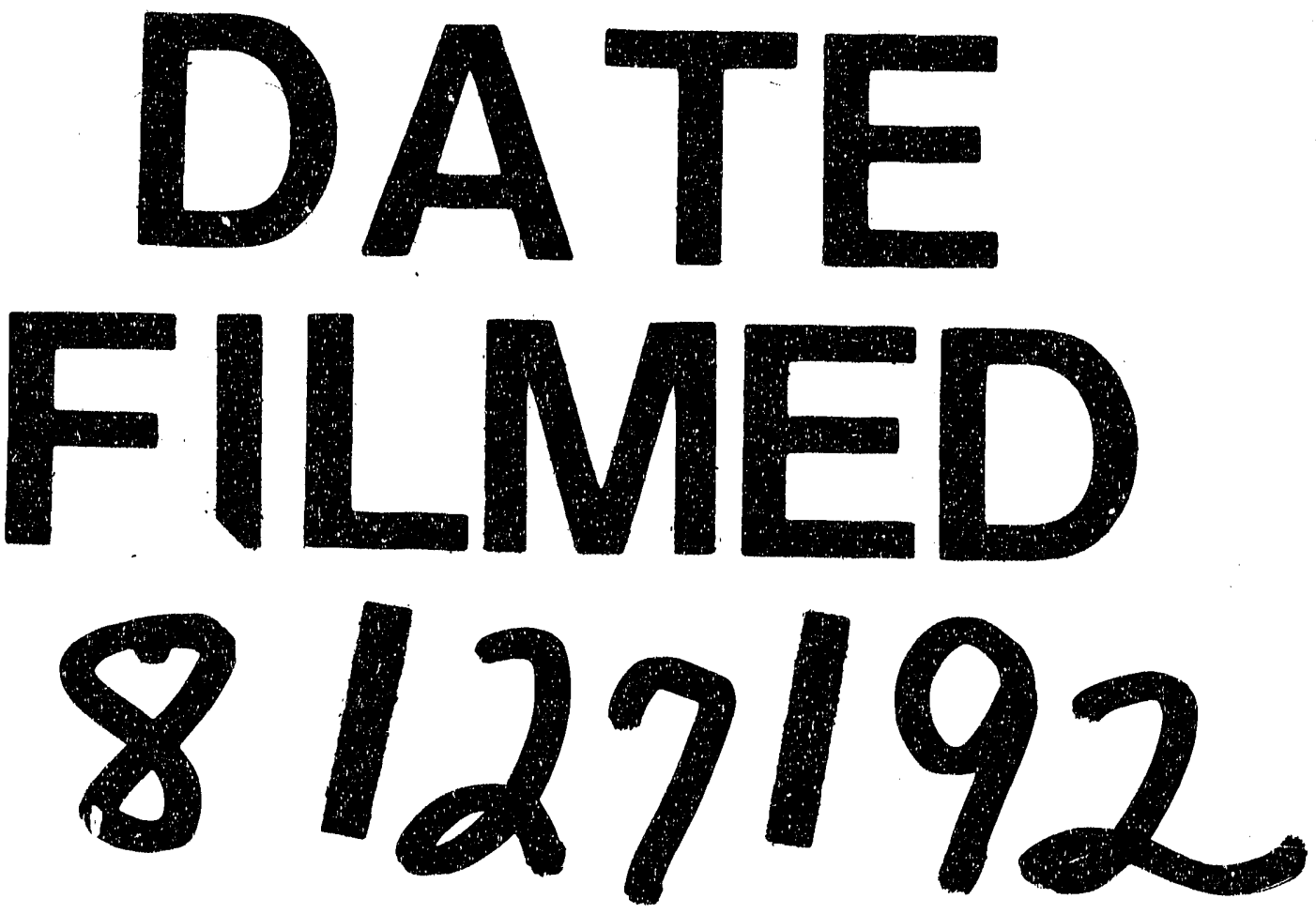
